\title{
Underlying Susceptibility to Eating Disorders and Drug Abuse: Genetic and Pharmacological Aspects of Dopamine D4 Receptors
}

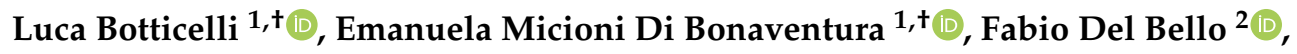 \\ Gianfabio Giorgioni ${ }^{2}{ }^{-0}$, Alessandro Piergentili ${ }^{2}$, Adele Romano ${ }^{3}$, Wilma Quaglia ${ }^{2}$, \\ Carlo Cifani $^{1, *, \neq(D)}$ and Maria Vittoria Micioni Di Bonaventura ${ }^{1, \ddagger(D)}$ \\ 1 School of Pharmacy, Pharmacology Unit, University of Camerino, via Madonna delle Carceri, 9, \\ 62032 Camerino, Italy; luca.botticelli@unicam.it (L.B.); emanuela.micioni@unicam.it (E.M.D.B.); \\ mariavittoria.micioni@unicam.it (M.V.M.D.B.) \\ 2 School of Pharmacy, Medicinal Chemistry Unit, University of Camerino, via S. Agostino, 1, \\ 62032 Camerino, Italy; fabio.delbello@unicam.it (F.D.B.); gianfabio.giorgioni@unicam.it (G.G.); \\ alessandro.piergentili@unicam.it (A.P.); wilma.quaglia@unicam.it (W.Q.) \\ 3 Department of Physiology and Pharmacology “V. Erspamer", Sapienza University of Rome, \\ P.le Aldo Moro 5, 00185 Rome, Italy; adele.romano@uniroma1.it \\ * Correspondence: carlo.cifani@unicam.it \\ + These authors contributed equally to this work. \\ $\ddagger$ These authors jointly supervised this work.
}

Received: 4 July 2020; Accepted: 27 July 2020; Published: 30 July 2020

check for updates

\begin{abstract}
The dopamine D4 receptor (DRD4) has a predominant expression in the prefrontal cortex (PFC), brain area strictly involved in the modulation of reward processes related to both food and drug consumption. Additionally, the human DRD4 gene is characterized by a variable number of tandem repeats (VNTR) in the exon 3 and, among the polymorphic variants, the 7-repeat (7R) allele appears as a contributing factor in the neurobiological mechanisms underlying drug abuse, aberrant eating behaviors and related comorbidities. The $7 \mathrm{R}$ variant encodes for a receptor with a blunted intracellular response to dopamine, and carriers of this polymorphism might be more tempted to enhance dopamine levels in the brain, through the overconsumption of drugs of abuse or palatable food, considering their reinforcing properties. Moreover, the presence of this polymorphism seems to increase the susceptibility of individuals to engage maladaptive eating patterns in response to negative environmental stimuli. This review is focused on the role of DRD4 and DRD4 genetic polymorphism in these neuropsychiatric disorders in both clinical and preclinical studies. However, further research is needed to better clarify the complex DRD4 role, by using validated preclinical models and novel compounds more selective for DRD4.
\end{abstract}

Keywords: dopamine D4 receptor (DRD4); drug addiction; food addiction; eating behavior; 7-repeat allele; obesity; prefrontal cortex; reward; DRD4 agonist; DRD4 antagonist

\section{Introduction}

Dopamine (DA) is a catecholamine neurotransmitter expressed both in the mammalian central nervous system (CNS) and in a variety of peripheral tissues. Within the brain, four principal dopaminergic networks have been identified: (I) the nigrostriatal pathway that includes neurons projecting from the substantia nigra pars compacta to the caudate putamen in the dorsal striatum, whose degeneration is responsible for Parkinson's disease [1,2]; (II) the mesolimbic pathway, including projections from the ventral tegmental area (VTA) to the nucleus accumbens (NAc) and olfactory tubercles, particularly involved 
in reward processes [3]; (III) the mesocortical network, that originates from neurons in the tegmentum and projects to the frontal cortex, mainly in the medial prefrontal regions, implicated in cognitive functions and motivation [4]; (IV) the tuberoinfundibular pathway that arises in the arcuate nucleus and ends in the median eminence of the hypothalamus, implicated in the neuroendocrine regulation and in the prolactin release [5-8]. In peripheral organs, DA is involved in several physiological functions including vision, olfaction, cardiovascular, hormonal and sympathetic regulation [5,9]. DA acts by binding five distinct receptors that are members of the G-protein coupled receptor superfamily. These proteins are characterized by seven hydrophobic transmembrane regions and a crucial third intracytoplasmic loop that interacts with different types of G-proteins and multiple effector molecules [5,7,9]. According to the biochemical and pharmacological features, these receptors are divided into the D1-like family, which includes D1 and D5 receptor subtypes (DRD1 and DRD5), and the D2-like family, comprising D2, D3 and D4 receptor subtypes (DRD2, DRD3 and DRD4). D1-like receptors activate the enzyme adenylyl cyclase, through a Gs-type protein, increasing levels of the second messenger cyclic adenosine monophosphate (cAMP), while D2-like receptors, coupling to a Gi or Go protein, inhibit the adenylyl cyclase, reducing cAMP concentrations $[5,8,10,11]$. In addition to the ability to modulate cAMP levels through adenylyl cyclase, D1-like and D2-like receptors are also able to activate other transductional signaling pathways. In particular, the stimulation of D1-like receptors results in the mobilization of intracellular calcium stores via the activation of phospholipase $C$, while the stimulation of D2-like receptors increases potassium and suppresses calcium currents, leading to cell hyperpolarization [8-11].

Within the D1-like class, DRD1 has the highest levels of expression in the brain: specifically, DRD1 mRNA has been found in neurons of the caudate putamen, olfactory tubercule, NAc, amygdala, substantia nigra and frontal cortex; low levels were also detected in hippocampus and thalamic areas $[5,7,11]$. In contrast, DRD5 are less expressed compared to the DRD1 subtype and are predominantly found within the hippocampus, parafascicular nucleus of the thalamus, cerebral cortex and dentate gyrus $[5,9,12-14]$.

With regard to D2-like family, the main localization of the DRD2 is in the caudate putamen, olfactory tubercle and NAc, and the expression was also detected in the substantia nigra pars compacta and in the VTA $[8,10]$. The distribution of DRD3 is limited to the limbic area, olfactory tubercle and island of Calleja and, at lower levels, in the substantia nigra and VTA [7-9]. Finally, the expression of the DRD4 has been found predominantly in the frontal cortex, hippocampus, amygdala, hypothalamus and mesencephalon, while lower levels were detected in the basal ganglia $[5,8,9,15]$.

Despite the limited expression in the brain compared to the other receptor subtypes, the DRD4 is particularly interesting because of the highly polymorphic nature of the human gene encoding for this protein $[16,17]$ and because several human studies revealed DRD4 possible involvement in neuropsychiatric diseases, including attention deficit hyperactivity disorder (ADHD) [18,19], personality traits of novelty seeking [20,21], schizophrenia [22,23], psychostimulants addiction [24], mood disorders [25], eating disorders (ED) [26-28] and obesity [29,30]. In this review, after a brief description of the DRD4, we will revise the current literature linking this receptor and DRD4 gene polymorphism to the development of drug addiction and aberrant ED, including binge eating behavior and obesity, describing the possible role played by the DRD4 in neural mechanisms implicated in these neuropsychiatric disorders.

\section{The Dopamine D4 Receptor}

The DRD4 is encoded by the DRD4 gene, localized on chromosome 11p15.5. This gene contains four exons and is highly polymorphic in the coding sequence. The most extensive polymorphism is present in the Exon3, a region that codes for the putative third intracytoplasmic loop of the receptor $[16,17,31]$. This polymorphism is characterized by a variable number of tandem repeat (VNTR), in which a 48-base-pair sequence exists as 2- to 11-fold repeat [15-17,31]. Allele frequencies of polymorphic variants of the DRD4 gene differ among several human populations, with the 4-repeat (4R) being the most common (64\%), followed by the 7-repeat (7R) (21\%) and the 2-repeat (2R) alleles $(8 \%)[15,31]$. Interestingly, it has been demonstrated that VNTR polymorphism influences DRD4 
coupling to the adenylyl cyclase; in fact, DA is twice as potent in the blockade of forskolin-induced cAMP accumulation on $2 R$ and $4 R$ than on $7 R$ receptor variant, suggesting that the $7 R$ allele encodes for a receptor with a reduced affinity for DA [16,32].

Although DA is the most potent endogenous ligand able to activate the DRD4, also noradrenaline and adrenaline, at submicromolar concentrations, activate DRD4, while histamine and serotonin do not show significant affinity for this receptor [33,34]. The activation of DRD4 not only inhibits cAMP production but also opens the Kir3 potassium channel, induces arachidonic acid release, activates extracellular signal-regulated kinase ERK1 and 2 and reduces the level of functional GABAa receptors [15].

The distribution pattern of DRD4 in the brain principally involves the cerebral cortex, amygdala, hippocampus, hypothalamus, and pituitary gland and, even though at lower levels, the basal ganglia, as assessed through Northern Blot and RT-PCR [35-37], in situ hybridization [38,39], and immunohistochemistry studies [40-44]. Moreover, high concentrations of DRD4 mRNA were detected also in the human retina [35]. The expression profile of the DRD4 is not limited to the CNS, considering that it was also found in the cardiac atrium [45], lymphocytes [46] and kidney [47].

The neuroanatomical profile of the DRD4 is different from the other DA receptor subtypes, strongly expressed in the striatum [48], because the predominant localization is in the prefrontal cortex (PFC) $[40,42,43]$. The PFC is a brain region associated with executive functions, such as working memory, novelty seeking and emotional processes [49,50]; specifically, the DRD4s are positioned on inhibitory GABAergic interneurons and on excitatory glutamatergic pyramidal neurons, including the striatal projections [51-53].

This localization is an important evidence of DRD4 ability to modulate GABAergic neurotransmission [43]. Additionally, a recent preclinical study reported that DRD4s, situated postsynaptically on pyramidal neurons, are able to modulate glutamatergic corticostriatal neurotransmission [54]. The significant role of the DRD4 as a modulator of the neural network activity was confirmed by studies using mice lacking the DRD4, which demonstrated an increased cortical hyperexcitability in the frontal cortex [55] and hypervigilant state and abnormal behavioral responses to environmental stimuli compared to wild-type mice (WT) [56]. These findings suggest that DRD4 has a critical role in the regulation of neurotransmission at the level of frontocortical areas of the brain and the dysregulation of dopamine DRD4-mediated signaling might be responsible of several pathological neuropsychiatric conditions.

\section{DRD4 and Drug Addiction}

Addiction is defined as a chronically relapsing disorder characterized by three main stages: (1) compulsive drug seeking and intake, (2) loss of control in limiting drug intake, (3) emergence of a negative emotional state (e.g., anxiety, dysphoria, irritability) when access to the drug is precluded [3].

The mesolimbic DA pathway is the principal neural network involved in reward processes and includes projections from the VTA to the NAc, but other pathways are implicated in drug addiction, the mesocortical (projections from VTA to the frontal cortex) and the mesostriatal (projections from the substantia nigra to the dorsal striatum) [57]. The rewarding effects of drugs of abuse are associated with the ability to release DA in the NAc, located in the ventral striatum [58], and the amount of released DA is correlated to the subjective perception of the drug as rewarding [59].

Due to the involvement of DA in motivational processes, the increased DA signaling associated with drugs and drug-related cues is able to enhance the motivation to obtain the reward [60]. In fact, according to "incentive salience hypothesis" proposed by Berridge and Robinson, DA assigns "incentive salience" to objects and behavioral acts and converts the neural representation of a stimulus into an attractive object that animals will try to obtain [61]. Thus, the reinforcing effect of drugs of abuse is due not only to the pleasurable property but mainly to the fact that, increasing DA transmission, they are considered as salient stimuli that will stimulate consumption of more drug, regardless of whether it is pleasurable or not [59].

Repeated exposure to substances of abuse results in neuroadaptations of the brain reward system and, in particular, it is observed a significant reduction of DRD2 and of DA released by DA cells [62]. 
Changes of DRD2 levels in addictive individuals in the striatum also contribute to reduced activity of prefrontal regions, including the anterior cingulate cortex, the orbitofrontal cortex and the dorsolateral PFC [63], where also DRD4 is widely expressed [40-42], and this neuroadaptation of frontocortical areas may be responsible of compulsive drug-seeking behaviors [64]. The PFC is a heterogenous area of the brain that is implicated in reward processes, due to its known role in value-based decision making and in inhibitory control [65]. The three regions of the PFC principally involved in the reward system are the dorsal anterior cingulate cortex, the ventromedial PFC and the orbitofrontal cortex [66]. It has been observed that the PFC sends glutamatergic projections to the VTA and thus exerts an excitatory control, by inducing cell firing of dopaminergic neurons, an event considered crucial for the central effects of drugs of abuse [67]. As mentioned above, DRD4 modulates glutamatergic corticostriatal neurotransmission [54], and since the VTA projects to the basal ganglia, it is believed that glutamatergic projections from the PFC could be responsible for the onset of incentive salience [68], process in which the DRD4 could be deeply involved. In fact, the exposure to drug-related cues induces activation of glutamatergic projections from the PFC, hippocampus and amygdala to striatal projections, leading to an increased DA release in the NAc and dorsal striatum [69]. Moreover, the PFC, essential in processing and filtering emotionally relevant sensory information, modulates input from the VTA and the amygdala, and this neuronal pathway is involved in encoding learned associations among sensory stimuli and emotionally salient events [51,70,71]. Disruption of this pathway, in which DRD4 seems to play a critical role [72,73], can lead to psychiatric disorders, including drug dependence, food addiction and ED.

Due to the predominant localization of the DRD4 in the PFC [74] and the involvement of the DRD4 gene polymorphism with personality traits of novelty seeking, impulsivity and risk-taking behaviors $[20,21,75]$, the DRD4 has been extensively studied in the context of drug addiction. In the next paragraphs we will analyze genetic studies linking the DRD4 gene to substance abuse and preclinical studies that investigated the role of this receptor in drug dependence.

\subsection{Polymorphism of DRD4 Gene and Drug Addiction}

The highly polymorphic nature of the DRD4 gene seems to be a potential genetic susceptibility factor to the development of substance abuse and is correlated with addiction and addiction associated-phenotypes [76-78].

Hutchinson et al. found that carriers of the 7R allele of the DRD4 gene or longer (DRD4 L) had more "urge to drink" and an increased craving after alcohol consumption than carriers of short allele (DRD4 S) [79]. DRD4 L individuals also reported less subjective stimulation and euphoria following alcohol administration, suggesting that they could be more motivated to engage activities that induce DA release [79]. Polymorphic variants of the DRD4 gene appear also to influence pharmacological efficacy in the treatment of Alcohol Use Disorder: it was demonstrated that olanzapine, an atypical antipsychotic, which is a DRD4 and DRD2 antagonist with also high affinity for serotonergic, muscarinic, histamine, and $\alpha$-1-adrenergic receptors, reduced craving elicited by alcohol cues only in DRD4 L carriers, but not in DRD4 S carriers [80,81]. Indeed, Naltrexone, an opiate antagonist used in the treatment of alcohol dependence [82], decreased heavy drinking and craving during non-drinking times only in DRD4 L carriers $[83,84]$. Moreover, Fibey et al. found a greater activation of the striatum, orbitofrontal cortex and anterior cingulate in carriers of the DRD4 L before a priming dose of alcohol but not after the administration $[77,85]$. Other works demonstrated an association between $7 \mathrm{R}$ allele and excessive alcohol intake, proposing that this relationship could be mediated by personality traits of novelty seeking [86,87]. A similar result was obtained by analyzing smoking behaviors and novelty seeking in adolescents with or without the 7R allele [88]. In accordance with previous observations, in participants that performed an alcohol/money choice task after cue exposure, the presence of the $7 \mathrm{R}$ variant was associated with a greater valuation of alcohol [89]. However, a non-significant influence between DRD4 gene polymorphism and reactivity to alcohol-related cues has been observed by van den Windelberg et al. [90]. 
The 7R variant of the gene appears to affect also smoking behaviors and nicotine dependence, as demonstrated by Shields et al. study, in which African American individuals, but not Caucasian people, with this polymorphism, showed a high risk of smoking [91]. Carriers of this allele reported greater functional magnetic resonance imaging (fMRI) signal in brain regions like the right superior frontal gyrus of the PFC and right insula compared to non-carriers in response to smoking cues [92]. In line with these results, a previous study demonstrated that DRD4 VNTR polymorphism influences reactivity to smoking cues, and in particular DRD4 L individuals reported a significant increase in craving, attention and arousal during the exposure to smoking cues compared to DRD4 S individuals [93]. Smokers with the 7R allele consumed more cigarettes per day, reported both less reduction of craving and lower DA release in the ventral caudate and NAc after smoking [94]. Several works also reported that the presence of at least one copy of the DRD4 L was linked to a reduced likelihood to smoking cessation $[95,96]$ and to an increased reactivity to smoking related cues in ex-smokers, suggesting an influence of DRD4 VNTR in the abstinence from nicotine [97].

Additionally, the DRD4 L was correlated with an increased craving after heroin-related stimuli in Chinese heroin addicted population [98] and in Israeli male opioid-dependent subjects, compared to control group with no history of substance abuse [99], supporting the hypothesis that the 7R allele represents a potential susceptibility factor for the development of opioid dependence [100].

Finally, methamphetamine abusers revealed a significantly higher prevalence of the 7R allele than control subjects [101]; however, a different result was reported in Chinese male population of methamphetamine dependents, in which the presence of the DRD4 gene polymorphic variant did not seem to be relevant [102].

All together, these studies highlight the important role played by the DRD4 gene in the development of drug addiction. The presence of the $7 \mathrm{R}$ allele variant might be associated with a blunted DA signaling [32], leading to an increased susceptibility to addictive behaviors.

This speculation can be explained by the "reward deficiency syndrome", hypothesis in which individuals with a genetic predisposition to a deficient DA signaling in the reward system may be more tempted to enhance DA levels in the brain by the repetitive administration of drugs of abuse [103]. Genetic association studies are particularly important to understand the role played by the DRD4 in drug addiction, together with preclinical studies, using genetically modified mice and evaluating DRD4 selective compounds, discussed in the next section.

\subsection{Preclinical Studies}

Experiments with genetically modified mice, in particular DRD4 KO mice, support a possible role of the DRD4 in drug abuse. In 1997, Rubinstein et al. found that mutant mice completely lacking functional DRD4 showed a less spontaneous locomotor activity but were supersensitive to the locomotor stimulating effects of ethanol, cocaine and methamphetamine [104]. Locomotor activity is correlated with the addictive properties of psychostimulants [105], and the following studies reported similar results, confirming that DRD4 deficient mice exhibit a heightened locomotor sensitivity in response to psychostimulants [106-108]. Conversely, Thanos et al., measuring locomotor activity in conditioned place preference (CPP) chambers, found in DRD4 KO mice an attenuated response to amphetamine at the dose of $1 \mathrm{mg} / \mathrm{kg}$, but the same mice exhibited a greater response at the dose of $3 \mathrm{mg} / \mathrm{kg}$ compared to WT and heterozygotes, while no difference was observed in response to methylphenidate and cocaine among all genotypes [109]. In the same experiment, the effect of these psychostimulants was also evaluated on CPP. The CPP test is a well-validated protocol for the evaluation of the rewarding and adversive effects of drugs [110]. DRD4 KO mice treated with methylphenidate and amphetamine showed significant CPP, meanwhile treatment with cocaine had no significant effect compared to the other genotypes [109]. This evidence is in line with a recent study, in which the DRD4 seems not to play a significant role in acquiring CPP for cocaine, but it could affect extinction and reinstatement for CPP [111].

DRD4 appears to further affect novelty seeking, a behavior strongly associated with the increased risk of drug addiction [112-114], even though controversial results were reported. In Dulawa et al. 
work, DRD4 KO mice reduced the behavioral responses to novel stimuli, using three tests: open field, emergence and novel object test [115]. Indeed, the stimulation of the DRD4 with the DRD4 partial agonist RO-10-5824 was able to increase novel object exploration in mice [116].

On the contrary, in another study, DRD4 KO and WT mice did not significantly differ in novel object exploration and impulsivity [117]. Subsequently, Thanos et al. reported that a deficient DRD4 signaling was associated with increased novelty seeking behavior in mice, but this effect was sex dependent and mainly observed in male mice [118]. In the same study, DRD4 depleted mice were less aggressive than control WT mice in a social interaction test, but became more aggressive after alcohol withdrawal [118]. Similarly, in humans the 7R allele of the DRD4 gene is associated with a higher craving following alcohol consumption [79] and craving is positively correlated with aggressive behaviors [119].

Mutant mice lacking DRD4 offer an interesting and important tool to understand the role of the DRD4 in the neurobiology of drug addiction, but results should be carefully interpreted, considering the compensatory changes observed in the brain of DRD4 deficient mice [120].

\section{Comparison Between DRD4 Antagonists and Agonists in Drug Addiction}

The possible role of the DRD4 in drug addiction led researchers to evaluate the effects of DRD4 selective compounds on drug-taking behaviors in animal studies.

The highly selective DRD4 antagonist L-745,870 (>2000-fold and >5000-fold selectivities over, respectively, DRD2 and DRD3, and $>20,000$-fold selectivity over DRD1 and DRD5 and a moderate affinity for sigma, 5-HT2 and $\alpha$-adrenergic receptors [121,122]) did not show efficacy in the reduction of the discriminative stimulus of cocaine in rats [123,124]. However, positive results were obtained in other studies, in which the blockade of DRD4 with the same antagonist attenuated methamphetamine-induced discriminative effect in rats $[125,126]$ and morphine-induced withdrawal symptoms precipitated by naloxone [127]. Additionally, a recent study by Kim et al. reported that L-745,870 decreased alcohol self-administration and stress-induced reinstatement, without influencing cue-induced reinstatement [128].

The same DRD4 antagonist was able to attenuate reinstatement of both nicotine- and cue-induced nicotine seeking behavior [129] even though ineffective in decreasing nicotine self-administration, suggesting the possible efficacy of DRD4 antagonists in the prevention of tobacco smoking relapse.

The inability of L-745,870 to reduce nicotine self-administration can be assigned to the poor expression of DRD4 in the NAc [31,42], proposing a limited effect in the modulation of the reinforcing properties of drugs of abuse. On the contrary, the significant effect in the reduction of reinstatement for nicotine can be explained by the DRD4 predominant localization in brain regions like the insular cortex or the frontal cortex. The activation of these brain areas has been critically correlated with the exposure to nicotine-related cues and reinstatement of nicotine-seeking behaviors [130,131].

Moreover, intraaccumbal admninistration of L-750,667, another DRD4 antagonist (>2000-fold selectivity over DRD2 and DRD3 and little affinity for DRD1, DRD5, sigma, 5-HT1A and 5-HT2 receptors [132]), failed to attenuate reinstatement of cocaine-seeking behaviors in rats [133], confirming the role of the DRD4 in relapse to drugs of abuse that is principally mediated by cortical regions of the brain and marginally in accumbal regions. The DRD4 also influences behavioral sensitization induced by psychostimulants. In fact, the blockade of the DRD4 with the selective antagonist PNU-101387G, with high affinity for DRD4 and relatively low for the other monoamine receptors, prevented amphetamine induced-behavioral sensitization [134].

Taking into account these results, DRD4 antagonists can be considered in the treatment of drug addiction, since they prolong abstinence and do not increase drug-self administration [24]. Thus, the blockade of DRD4 may reduce the risk of abuse liability in humans by influencing motivational processes associated with drug-intake [24,128].

It cannot be excluded that pharmacological activation of the DRD4 might also be a useful approach to treat drug addiction, considering that the DRD4 agonist PD-168,077 ( $>400$-fold selectivity over the DRD2 and $>300$-fold selectivity versus DRD3 but affinity also for $\alpha$-adrenergic receptors as well as 
5-HT1A and 5-HT1B receptors [135,136]) was able to decrease morphine-induced hyperlocomotion, reward and withdrawal syndrome, without interfering with the analgesic properties [137]. This activity seems to be caused by a functional interaction between DRD4 and $\mu$-opioid receptor [138] in the striosomal compartments of the caudate putamen and substantia nigra pars reticulata, regions in which these receptors are co-expressed $[44,139]$. In fact, the stimulation of DRD4 with a selective agonist is able to reduce the activation of the nigrostriatal pathway induced by morphine, to restore DA tone [137] and to prevent morphine-induced expression of several transcription factors as well as long-term $\mu$-opioid receptor sensitization in the caudate putamen [140-143].

Moreover, DRD4 stimulation does not exhibit reinforcing properties, conversely to psychostimulant drugs [24]. In fact, the DRD4 agonist ABT-724, tested in rhesus monkeys trained to self-administer cocaine, was not able to maintain the rates of self-administration behavior [144]. However, the inefficacy of this compound was probably due to the profile of partial agonist, while a full agonist could have been more effective [144]. Accordingly, A-412997, another DRD4 agonist ( $>300$-fold selective over other DA receptors, and 125-fold over 5-HT1A receptors [136]), did not induce CPP in rats [145] in contrast to amphetamine, not resulting in reward related behaviors. These findings confirmed that the stimulation of the DRD4 did not serve a reinforcing function, suggesting that the DRD4 could be an innovative target for the development of new therapeutic strategies for drug addiction and other addictive behaviors. All compounds were summarized in Table 1.

Table 1. Dopamine D4 receptor (DRD4) compounds in drug addiction.

\begin{tabular}{|c|c|c|c|c|}
\hline Compounds & $\begin{array}{l}\text { Type of } \\
\text { Interaction }\end{array}$ & Species & Effect & References \\
\hline \multirow{4}{*}{$\mathrm{L}-745,870$} & \multirow{4}{*}{ Antagonist } & Rats & $\begin{array}{l}\text { Reduction of methamphetamine-induced } \\
\text { discriminative effect }\end{array}$ & [125] \\
\hline & & Mice & $\begin{array}{l}\text { Reduction of morphine-induced } \\
\text { withdrawal }\end{array}$ & [127] \\
\hline & & Rats & $\begin{array}{l}\text { Reduction of reinstatement of both } \\
\text { nicotine- and cue-induced nicotine } \\
\text { seeking behavior }\end{array}$ & [129] \\
\hline & & Rats & $\begin{array}{l}\text { Reduction of alcohol self-administration } \\
\text { and stress-induced reinstatement }\end{array}$ & [128] \\
\hline L-750,667 & Antagonist & Rats & $\begin{array}{l}\text { Does not attenuate reinstatement of } \\
\text { cocaine-seeking behaviors }\end{array}$ & [133] \\
\hline PNU-101387G & Antagonist & Rats & $\begin{array}{l}\text { Prevention of amphetamine } \\
\text { induced-behavioral sensitization }\end{array}$ & [134] \\
\hline ABT-724 & $\begin{array}{l}\text { Partial } \\
\text { Agonist }\end{array}$ & $\begin{array}{l}\text { Rhesus } \\
\text { Monkeys }\end{array}$ & $\begin{array}{l}\text { Does not maintain the rates of cocaine } \\
\text { self-administration behavior }\end{array}$ & [144] \\
\hline PD-168,077 & Agonist & Rats & $\begin{array}{l}\text { Decrease of morphine-induced } \\
\text { hyperlocomotion, reward and } \\
\text { withdrawal syndrome }\end{array}$ & [137] \\
\hline A-412997 & Agonist & Rats & $\begin{array}{l}\text { Does not induce CPP compared to } \\
\text { amphetamine and methamphetamine }\end{array}$ & [145] \\
\hline
\end{tabular}

\section{DRD4 and Feeding Behavior}

The DRD4 gene polymorphism seems to affect the cue-elicited craving not only for drugs of abuse but also for natural stimuli, such as food [146]. Interestingly, an overlap between the neural mechanisms implicated in the appetitive motivation for drugs and those involved in appetitive motivation for food was reported, supporting the "food addiction" hypothesis [146-149]. Accordingly, both drugs of abuse and food consumption (especially addictive food) activate the same brain pathway involved in reward 
and motivation [150], where the dopaminergic signaling is the principal neurotransmission system; the increase of DA levels in those brain areas could reinforce the effects of addiction [151].

As mentioned above, the DRD4 is the only D2-like subtype strongly expressed in PFC [40,42,43], brain region that modulates drug craving, but also the rewarding properties of foods [152]. In fact, the PFC has anatomical connections with feeding-related areas, including the lateral hypothalamus, NAc shell and limbic reward sites $[153,154]$. The PFC circuitry is linked with cognitive aspects of searching for food [155], self-control, salience attribution and awareness [156], reward-based decision-making [66], and a dysregulation of such circuit might lead to the development of obesity [157-160]. In keeping with this latter observation, different imaging studies suggested the PFC activation in response to food-related cues [161-163]; such activation is also implicated in yohimbine-induced reinstatement of food seeking in rodents [164,165].

Furthermore, the PFC is involved in stress response $[166,167]$ and interacts with the hypothalamicpituitary adrenal (HPA) axis [168]. Specifically, Armbruster et al. examined the impact of DRD4 polymorphism on HPA activity, showing a significant smaller cortisol response to social stress in healthy adult carriers of the 7R allele [169]. Cortisol reactivity and the stress neurohormone corticotropin-releasing factor (CRF) effects, via HPA axis and extrahypothalamic brain site, may be a marker for vulnerability to stress, inducing binge eating and subsequent ED. Remarkably, the episode of binge eating is associated with high cortisol levels [170-175] that predict sweet food overeating [176], and CRF receptors were demonstrated to play a pivotal role in stress induced binge eating in several studies [177-185].

These considerations on DRD4 distribution and the role in drug dependence, previously debated, provide evidence on the potential implication of DRD4 signaling in ED and obesity.

Over the last few years, considerable progress has been made to understand the neurobiological mechanisms that underlie ED, converging that genetic factors and gene/environment interactions could contribute to the potential development of these disorders [186-189]. One of the possible candidates that may contribute to the dysregulation of feeding patterns in ED and risk of weight gain, leading to obesity, is the polymorphism of DRD4 gene. In this context, several studies identified the genetic variability of DRD4 as a factor in binge eating behavior, bulimia nervosa (BN) and anorexia nervosa (AN) as well as overweight $[26-28,190]$. Binge eating is a typical symptom in ED, in particular BN, binge/purging subtype of AN and binge eating disorders (BED), characterized by an excessively compulsive intake of palatable food in a discreet period of time [191]. Differently from AN and BN, individuals with BED do not engage in regular compensatory behaviors after binging, such as induced vomiting, laxative misuse and prolonged fasting [191]. Therefore, it is frequently associated with overweight or severity of obesity [192]. Commonly, the episode of binge eating occurs on energy dense food that promotes non-homeostatic eating [28], eating in the absence of hunger [193], and the activation of the brain reward systems [194]. Further to the hedonic and addictive value, palatable food becomes a "comfort food", provoking binge eating behavior, to alleviate anxiety and stress responses [195]. Similarly, to drug abuse, this comfort, especially during dietary periods, encourages to the overconsumption of caloric food [196,197] and sustains the "dark side" of food addiction [198].

\subsection{The Influence of the DRD4 Gene Polymorphism in Eating Disorders and Obesity}

In 1998, Poston et al. was one of the first to investigate an association between the long version of the DRD4 gene and the risk to develop dysfunctional eating patterns, observing that DRD4 L was more frequent in female and male subjects with higher risk for obesity, independently of the degree of body mass index (BMI). They measured the duration of obesity state, parental obesity, severe obesity and novelty-seeking-related scales of the Karolinska Scales of Personality [30]. Although the work was limited only to obese patients with a small range of BMI, without a direct correlation between the Karolinska Scales of Personality and DRD4 long allele, the results of this study revealed an association between this polymorphism and obesity susceptibility.

Subsequently, in two studies [28,29], Levitan et al. investigated a possible role of 7R allele of the DRD4 gene in binge eating behavior and obesity in a group of overeating women with Seasonal Affective 
Disorder (SAD). SAD is a subtype of Major Depressive Disorder derived from an interaction among biologic disturbances, mood states and seasonal changes $[199,200]$. Patients with SAD show prevalently hyperphagia and marked craving for high-carbohydrate and high-fat foods, during depressive episodes or negative mood states driving to BED with a consequent weight gain $[199,201,202]$. Levitan et al. works revealed a significant association between $7 \mathrm{R}$ allele and the greater risk of binge eating behavior and overeating that contributes to a high maximal BMI, due to a possible low DA activity in PFC [28,29].

Kaplan et al. continued to study the 7R allele contribution on BMI, analyzing blood samples of women with BN, purging subtype, and they found a positive correlation between this polymorphism and the maximal lifetime BMI [27]. Additionally, it appeared to affect not only the BMI, but even the personality-related psychopathologies common in BN patients, such as increased novelty seeking and impulsivity $[190,203]$.

In accordance with the high prevalence of ED in adolescents and specially in young women [204,205], Sikora study was focused on females. It revealed that women, carriers of at least one copy of DRD4 L allele, reported an increased BMI, and the highest BMI was observed in women 7R/7R homozygotes, in comparison to the other DRD4 polymorphisms [206]. These findings demonstrated that this variant can lead to an excessive food intake to compensate the impaired DA transmission, extending the previously mentioned "reward deficiency syndrome" from drug to food addiction [32,103,206,207]. Other studies highlighted the relationship between the DRD4 gene polymorphism and environmental influences, suggesting that this interaction could play a key role in the promotion of overeating and weight gain.

The season of birth could be considered an environmental factor able to affect eating behaviors; in fact, women with SAD and carriers of the 7R variant, born in spring, exhibited a major risk to develop weight gain and obesity [208], conversely, females with BN and the same allele, showed the highest BMI if born in fall [209]. Additionally, Van Strien et al., studying the influence of the season of birth in males and females with 7R allele of the DRD4 gene, found this effect more pronounced in young women, especially when born in fall, revealing an increased risk of emotional eating [210]. The emotional eating is characterized by a tendency to eat after exposure to stress or negative emotions, preferring sugars and saturated fat items [211], often leading to binge eating [212-214].

Furthermore, in two different studies, Silveira et al. showed that preschoolers, carriers of the 7R variant, had different food preferences, depending on sex: girls had less healthy nutrition, eating more fat food than boys [215], suggesting a greater vulnerability to develop weight gain and ED, which could increase if they lived in adverse environments [216]. In support of this last evidence, recent research indicated a reduced risk to maladaptive eating behaviors in children raised in a positive environment with a high predicted prefrontal DRD4 gene expression, measured by an innovative machine learning prediction system (PrediXcan). On the contrary, children with the same predicted gene expression, living in a less positive environment, developed obesogenic behaviors, including overconsumption of high sugar drinks and emotional eating [217]. Moreover, another relationship between a negative environmental factor and the variation of the DRD4 gene is represented by a history of low maternal sensitivity in girls with the 7R allele, promoting overweight and thus the risk to become obese [218].

Taken together, this evidence shows that the 7R allele seems to increase the susceptibility to multiple environmental factors, and thus, individuals, carriers of this polymorphic variant, are more prone to overweight and dysfunctional eating patterns. Furthermore, the polymorphism of the DRD4 gene is associated with reward seeking behaviors: adults with versus without the 7R variant exhibited a greater craving in response to food cues, predisposing them to binge eating behavior [146]. Then, Stice et al. observed, through an fMRI study, a correlation between the 7R allele and reduced activity in the reward circuitry in adolescent girls, with a different range of BMI, in response to palatable food imagines, predicting unhealthy weight gain [219]. Comparing overweight with adolescent lean girls, the first ones exhibited more activity in the ventrolateral PFC, a factor which is positively correlated with BMI, due to the role of this area on directing attention to palatable food [219,220]. In a following study, always using the fMRI paradigm, Stice et al. continued to investigate the brain response to receipt and anticipated receipt of palatable food in lean adolescents, with different genotypes related to low dopaminergic 
transmission, including 7R or longer allele. Alterations in cerebral areas sensitive to food reward were found in these adolescents, which might perceive the food reward more salient [221].

The polymorphism of the DRD4 gene not only influences BMI and overeating but also the development of AN and correlated psychopathological features. Supporting this hypothesis, several researches found a strong association between the 7R genotype and the risk of AN [222]. Probably, this association is caused by disturbances in the food reward circuitries [223] and by the involvement of DRD4 gene polymorphism in the psychopathological features, especially perfectionism and body dissatisfaction in patients with AN [26]. The various studies that investigated the effect of the DRD4 polymorphism are listed in Table 2.

Table 2. The effect of the 7R or longer allele (DRD4 L) in eating patterns.

\begin{tabular}{|c|c|c|c|}
\hline Subjects of Study & Genotype & Result & Reference \\
\hline Patients with BMI $>30$ & DRD4 L vs. DRD4 S & $\begin{array}{l}\text { Dysfunctional eating patterns } \\
\text { that promote obesity }\end{array}$ & {$[30]$} \\
\hline SAD women & 7R vs. no 7R allele & $\begin{array}{l}\text { Binge eating behavior and } \\
\text { increased BMI }\end{array}$ & {$[28,29]$} \\
\hline BN women & 7R vs. no 7R allele & Increased BMI & [27] \\
\hline $\mathrm{BN}$ patients & 7R vs. no 7R allele & $\begin{array}{l}\text { Affect personality-related } \\
\text { psychopathologies }\end{array}$ & [203] \\
\hline $\mathrm{BN}$ patients & 7R vs. no 7R allele & $\begin{array}{l}\text { Affect personality-related } \\
\text { psychopathologies }\end{array}$ & [190] \\
\hline Women & DRD4 L vs. DRD4 S & Increased BMI & [206] \\
\hline SAD women & 7R vs. no 7R allele & $\begin{array}{l}\text { Weight gain and obesity in } \\
\text { SAD women born in spring }\end{array}$ & [208] \\
\hline $\mathrm{BN}$ women & 7R vs. no 7R allele & $\begin{array}{l}\text { High BMI in BN women born } \\
\text { in fall }\end{array}$ & [209] \\
\hline Young women & 7R vs. no 7R allele & $\begin{array}{l}\text { Emotional eating in young } \\
\text { women born in fall }\end{array}$ & [210] \\
\hline 4 years old children & 7R vs. no 7R allele & $\begin{array}{l}\text { Susceptibility to develop } \\
\text { weight gain and ED }\end{array}$ & [215] \\
\hline Preschooler children & 7R vs. no 7R allele & $\begin{array}{l}\text { Risk of obesity in women with } \\
\text { history of low maternal } \\
\text { sensitivity }\end{array}$ & [218] \\
\hline $\begin{array}{l}\text { Individuals with and without } \\
\text { symptoms of binge eating }\end{array}$ & DRD4 L vs. DRD4 S & $\begin{array}{l}\text { Craving predisposing to binge } \\
\text { eating behavior }\end{array}$ & [146] \\
\hline $\begin{array}{l}\text { Lean to obese adolescent } \\
\text { female }\end{array}$ & 7R vs. no 7R allele & Unhealthy weight gain & [219] \\
\hline AN women & 7R vs. no 7R allele & Risk to develop AN & [222] \\
\hline AN women & 7R vs. no 7R allele & $\begin{array}{l}\text { Affect personality-related } \\
\text { psychopathologies }\end{array}$ & [26] \\
\hline
\end{tabular}

AN: Anorexia Nervosa; BMI: Body Mass Index; BN: Bulimia Nervosa; DRD4 L: Dopamine D4 receptor long allele; DRD4 S: Dopamine D4 receptor short allele; ED: Eating Disorder; SAD: Seasonal Affective Disorder; 7R: 7-repeat.

Despite these positive correlations, it is important also to consider contrasting results on the effect of DRD4 gene polymorphism in AN and the other ED.

For instance, Hinney et al. found that the polymorphism of the DRD4 gene was not statistically relevant to the etiology of AN and obesity in German adolescents, but the study had the limit of not considering healthy subjects as a control group [224]. Guo et al. showed a reduction in BMI in African American and Hispanic young adolescent siblings, carriers of the 7R/7R genotype [225,226]. In addition, Fontana et al. found a higher BMI, energy intake and waist circumference in preschooler 
children without 7R allele compared to 7R carriers [227]. Accordingly, other studies corroborated no implication of DRD4 L on increased BMI $[228,229]$. Karwautz et al. described a non-significant association between DRD4 gene variants and AN, comparing 45 sister-pairs, one with AN and the other without any ED [230]. Furthermore, Yilmaz et al. observed a correlation between the 7R allele of the DRD4 gene and BN only if these patients had a history of childhood ADHD [231]. Finally, considering that the peripheral expression of dopaminergic genes reflects the brain status, Frieling et al. analyzed blood of patients suffering from ED and did not find a significant relationship between DRD4 gene and AN or BN [232]. These conflicting studies and the respective outcomes were shown in Table 3.

Table 3. The effect of the 7R or longer allele (DRD4 L) in eating patterns.

\begin{tabular}{llll}
\hline \multicolumn{1}{c}{ Subjects of Study } & \multicolumn{1}{c}{ Genotype } & \multicolumn{1}{c}{ Result } & Reference \\
\hline $\begin{array}{l}\text { Adolescent and young adult patients } \\
\text { with acute AN; underweight students; } \\
\text { children and adolescents with obesity }\end{array}$ & $\begin{array}{l}\text { Allelic variants of } \\
\text { DRD4 gene }\end{array}$ & $\begin{array}{l}\text { No evidence in etiology of AN } \\
\text { and obesity }\end{array}$ & [224] \\
\hline Adolescents and young adults & 7R vs. no 7R allele & $\begin{array}{l}\text { Reduction in BMI in African } \\
\text { American and Hispanic } \\
\text { individuals }\end{array}$ & [225,226] \\
\hline Children & 7R vs. no 7R allele & $\begin{array}{l}\text { Lower BMI, energy intake and } \\
\text { waist circumference }\end{array}$ & [227] \\
\hline $\begin{array}{l}\text { Overweight and obese compared to } \\
\text { normal weight adolescents }\end{array}$ & 7R vs. no 7R allele & $\begin{array}{l}\text { No evidence in increased BMI and } \\
\text { risk of obesity }\end{array}$ & [228] \\
\hline $\begin{array}{l}\text { Adolescents from lean to obese } \\
\text { Sister pairs: one with AN and the other } \\
\text { one with no history of any form of ED }\end{array}$ & Allelic variants of & DRD4 gene & No correlation with AN \\
\hline $\begin{array}{l}\text { Women with current or past BN } \\
\text { purging subtype, and a subgroup of } \\
\text { them with a childhood ADHD }\end{array}$ & 7R vs. no 7R allele & $\begin{array}{l}\text { No correlation with BN, if not } \\
\text { associated with ADHD }\end{array}$ & [229] \\
\hline
\end{tabular}

AN: Anorexia Nervosa; ADHD: Attention deficit hyperactivity disorder; BMI: Body Mass Index; BN: Bulimia Nervosa; DRD4: Dopamine D4 receptor; DRD4 L: Dopamine D4 receptor long allele; DRD4 S: Dopamine D4 receptor short allele; ED: Eating Disorder; 7R: 7-repeat.

\subsection{Preclinical Studies}

Taking into account these controversial results and the possible influence of DRD4 gene in eating behaviors and in the regulation of body weight in human studies, it would be interesting to deeply explore the role of the DRD4 in well characterized animal models of aberrant eating patterns.

Until now, very few preclinical studies have been done. Compared to WT, mutant mice lacking DRD4 showed similar behavioral responses in standard food pellets consumption under self-administration paradigm [233], and they did not reveal significant differences on the reinforcing effectiveness of food [234]. Other researches evidenced that clozapine, an atypical antipsychotic and a DRD4 antagonist, increased food intake in rats [235] and mice [236]. These results are consistent with clinical studies in which clozapine stimulates appetite and craving for carbohydrates and palatable food, leading to episodes of binge eating $[237,238]$ and weight gain because of the inability to suppress hyperphagia [239]. However, clozapine is not a selective DRD4 antagonist but has affinity for receptors of multiple neurotransmitters including serotonin, noradrenaline and histamine [240], and this could be the reason for the effect on appetite [241].

Afterwards, Huang et al. evaluated the mRNA DRD4 expression in the subcortical areas of the brain, in obesity prone or resistant mice, under chronic high-fat diet [242]. Using in situ hybridization techniques, compared to control (mice fed with low-fat diet) and obesity resistant mice, obesity prone mice had significantly higher levels of DRD4 mRNA expression in the ventral part of the lateral septal nucleus and ventromedial hypothalamic nucleus, suggesting a role for this receptor in the hypothalamic pathway [242]. Indeed, the DRD4, despite being predominantly expressed in the PFC, is also importantly localized in the hypothalamus [37,242], and it is well known that hypothalamic circuitries contribute to appetite control and energy homeostasis [243-247] by integrating a variety of 
neural inputs arising from both neuropeptides and neurotransmitters [248-255] and modulating the mechanisms underlying ingestive behavior and stress [256-258]. These findings suggest that the DRD4 may influence food intake and eating behaviors at the level of both the PFC, as previously discussed, and the hypothalamus. Interestingly, stimulation of the DRD4 with the selective agonist PD-168,077, directly injected in the paraventricular nucleus of the hypothalamus (PVN), induced hyperphagia in male rats, apparently caused by presynaptic inhibition of glutamate release in the PVN and, at the same time, it decreased plasma corticosterone levels in food-restricted rats [259]. Glutamate directly stimulates CRF neurons [260]. Thus, the authors speculated that the hyperphagia was induced by synergistic interaction among DRD4, glutamate and CRF.

Intriguingly, this effect was completely reversed by the pretreatment with the DRD4 antagonist L-745,870 that was inactive per se on food intake [260]. In another study [129], the same DRD4 antagonist had no effect on reinstatement of food seeking behavior in standard food pellets, elicited by food cues or food priming.

\section{Conclusions}

The findings herein support a potential relationship among DRD4 and the gene polymorphism, drug and food addiction. The localization and connectivity of DRD4, predominant in PFC and hypothalamus and related neuronal pathways present in these brain regions, in addition to DRD4 involvement on personality traits, especially novelty seeking and impulsivity, suggest a complex action of this DA receptor in addicted behavior. Consequently, the deficiency in DRD4 signaling, particularly evident in the 7R variant of the gene, could increase the susceptibility to the development of substance abuse or ED and related comorbidities. The DRD4 was intensively investigated in human studies and considerably less in animals, mostly in mutant mice lacking DRD4 and in the context of drug addiction. Genetic association studies are important to understand the role played by the DRD4 gene in the disorders discussed in this review; however, further research will be necessary to explain the controversial results debated above, especially a deep investigation using preclinical studies. It is important to consider, for instance, the compensatory changes observed in the brain of DRD4 KO mice and to extend the research to validated animal models of ED, in order to evaluate the effect of selective DRD4 agonists and antagonists on feeding behavior. To the best of our knowledge, the effect of DRD4 compounds on palatable food, as well as the possible role of DRD4 and adenosine $\mathrm{A}_{2 \mathrm{~A}}$ receptor $\left(A_{2 A} A R\right)$ heteromers [261-263] on compulsive behavior, has been unexplored since the promising results of $\mathrm{A}_{2 \mathrm{~A}} \mathrm{AR}$ agonists to block binge eating behavior and drug abuse [264-268]. Similarly, it would be interesting to investigate the interaction between sigma and DRD4 pathway, taking into account that they both modulate glutamate release and several DRD4 compounds bind also sigma1 receptors with high affinity $[122,269,270]$. Moreover, recent works highlighted the strong effect of sigma1 receptor antagonists to attenuate many behaviors related to drug abuse and binge eating episodes [271-274].

In summary, this review highlights the attractive role of DRD4 as an interesting pharmacological target and promotes the discovery of innovative selective compounds for the treatment of addictive disorders and their related comorbidities.

Author Contributions: L.B., E.M.D.B., F.D.B., W.Q., C.C. and M.V.M.D.B. conceptualization; L.B., E.M.D.B., C.C. and M.V.M.D.B. writing-original draft preparation; L.B., E.M.D.B., F.D.B., G.G., A.P., A.R., W.Q., C.C. and M.V.M.D.B. writing-review and editing; L.B., E.M.D.B., F.D.B., G.G., A.P., A.R., W.Q., C.C. and M.V.M.D.B. visualization; M.V.M.D.B. and C.C. supervision; F.D.B. and C.C. funding acquisition. All authors have read and agreed to the published version of the manuscript.

Funding: This research was funded by the University of Camerino: Fondo di Ateneo per la Ricerca 2018 and 2019 to F.D.B. and by the Italian Ministry of Education, University and Research: PRIN2015KP7T2Y to CC.

Conflicts of Interest: The authors declare no conflict of interest. 


\section{References}

1. Lang, A.E.; Lozano, A.M. Parkinson's disease. Second of two parts. N. Engl. J. Med. 1998, 339, 1130-1143. [CrossRef] [PubMed]

2. Lang, A.E.; Lozano, A.M. Parkinson's disease. First of two parts. N. Engl. J. Med. 1998, 339, $1044-1053$. [CrossRef] [PubMed]

3. Koob, G.F.; Sanna, P.P.; Bloom, F.E. Neuroscience of addiction. Neuron 1998, 21, 467-476. [CrossRef]

4. Le Moal, M.; Simon, H. Mesocorticolimbic dopaminergic network: Functional and regulatory roles. Physiol. Rev. 1991, 71, 155-234. [CrossRef]

5. Beaulieu, J.M.; Gainetdinov, R.R. The physiology, signaling, and pharmacology of dopamine receptors. Pharmacol. Rev. 2011, 63, 182-217. [CrossRef]

6. Maharajan, P.; Maharajan, V.; Ravagnan, G.; Paino, G. The weaver mutant mouse: A model to study the ontogeny of dopamine transmission systems and their role in drug addiction. Prog. Neurobiol. 2001, 64, 269-276. [CrossRef]

7. Tarazi, F.I. Neuropharmacology of dopamine receptors: Implications in neuropsychiatric diseases. J. Sci. Res. Med. Sci. 2001, 3, 93-104.

8. Vallone, D.; Picetti, R.; Borrelli, E. Structure and function of dopamine receptors. Neurosci. Biobehav. Rev. 2000, 24, 125-132. [CrossRef]

9. Missale, C.; Nash, S.R.; Robinson, S.W.; Jaber, M.; Caron, M.G. Dopamine receptors: From structure to function. Physiol. Rev. 1998, 78, 189-225. [CrossRef]

10. Civelli, O.; Bunzow, J.R.; Grandy, D.K. Molecular diversity of the dopamine receptors. Annu. Rev. Pharmacol. Toxicol. 1993, 33, 281-307. [CrossRef]

11. Ye, N.; Neumeyer, J.L.; Baldessarini, R.J.; Zhen, X.; Zhang, A. Update 1 of: Recent progress in development of dopamine receptor subtype-selective agents: Potential therapeutics for neurological and psychiatric disorders. Chem. Rev. 2013, 113, PR123-PR178. [CrossRef] [PubMed]

12. Meador-Woodruff, J.H.; Haroutunian, V.; Powchik, P.; Davidson, M.; Davis, K.L.; Watson, S.J. Dopamine receptor transcript expression in striatum and prefrontal and occipital cortex. Focal abnormalities in orbitofrontal cortex in schizophrenia. Arch. Gen. Psychiatry 1997, 54, 1089-1095. [CrossRef] [PubMed]

13. Sokoloff, P.; Schwartz, J.C. Novel dopamine receptors half a decade later. Trends Pharm. Sci. 1995, 16, $270-275$. [CrossRef]

14. Meador-Woodruff, J.H.; Mansour, A.; Grandy, D.K.; Damask, S.P.; Civelli, O.; Watson, S.J., Jr. Distribution of D5 dopamine receptor mRNA in rat brain. Neurosci. Lett. 1992, 145, 209-212. [CrossRef]

15. Rondou, P.; Haegeman, G.; Van Craenenbroeck, K. The dopamine D4 receptor: Biochemical and signalling properties. Cell. Mol. Life Sci. 2010, 67, 1971-1986. [CrossRef]

16. Ding, Y.C.; Chi, H.C.; Grady, D.L.; Morishima, A.; Kidd, J.R.; Kidd, K.K.; Flodman, P.; Spence, M.A.; Schuck, S.; Swanson, J.M.; et al. Evidence of positive selection acting at the human dopamine receptor D4 gene locus. Proc. Natl. Acad. Sci. USA 2002, 99, 309-314. [CrossRef]

17. Van Tol, H.H.; Wu, C.M.; Guan, H.C.; Ohara, K.; Bunzow, J.R.; Civelli, O.; Kennedy, J.; Seeman, P.; Niznik, H.B.; Jovanovic, V. Multiple dopamine D4 receptor variants in the human population. Nature 1992, 358, 149-152. [CrossRef]

18. LaHoste, G.J.; Swanson, J.M.; Wigal, S.B.; Glabe, C.; Wigal, T.; King, N.; Kennedy, J.L. Dopamine D4 receptor gene polymorphism is associated with attention deficit hyperactivity disorder. Mol. Psychiatry 1996, 1, 121-124.

19. Swanson, J.M.; Sunohara, G.A.; Kennedy, J.L.; Regino, R.; Fineberg, E.; Wigal, T.; Lerner, M.; Williams, L.; LaHoste, G.J.; Wigal, S. Association of the dopamine receptor D4 (DRD4) gene with a refined phenotype of attention deficit hyperactivity disorder (ADHD): A family-based approach. Mol. Psychiatry 1998, 3, 38-41. [CrossRef]

20. Benjamin, J.; Li, L.; Patterson, C.; Greenberg, B.D.; Murphy, D.L.; Hamer, D.H. Population and familial association between the D4 dopamine receptor gene and measures of novelty seeking. Nat. Genet. 1996, 12, 81-84. [CrossRef]

21. Ebstein, R.P.; Novick, O.; Umansky, R.; Priel, B.; Osher, Y.; Blaine, D.; Bennett, E.R.; Nemanov, L.; Katz, M.; Belmaker, R.H. Dopamine D4 receptor (D4DR) exon III polymorphism associated with the human personality trait of novelty seeking. Nat. Genet. 1996, 12, 78-80. [CrossRef] [PubMed] 
22. Seeman, P.; Guan, H.C.; Van Tol, H.H. Dopamine D4 receptors elevated in schizophrenia. Nature 1993, 365, 441-445. [CrossRef] [PubMed]

23. Tarazi, F.I.; Zhang, K.; Baldessarini, R.J. Dopamine D4 receptors: Beyond schizophrenia. J. Recept. Signal Transduct. Res. 2004, 24, 131-147. [CrossRef] [PubMed]

24. Di Ciano, P.; Grandy, D.K.; Le Foll, B. Dopamine D4 receptors in psychostimulant addiction. Adv. Pharmacol. 2014, 69, 301-321. [CrossRef] [PubMed]

25. Manki, H.; Kanba, S.; Muramatsu, T.; Higuchi, S.; Suzuki, E.; Matsushita, S.; Ono, Y.; Chiba, H.; Shintani, F.; Nakamura, M.; et al. Dopamine D2, D3 and D4 receptor and transporter gene polymorphisms and mood disorders. J. Affect. Disord. 1996, 40, 7-13. [CrossRef]

26. Bachner-Melman, R.; Lerer, E.; Zohar, A.H.; Kremer, I.; Elizur, Y.; Nemanov, L.; Golan, M.; Blank, S.; Gritsenko, I.; Ebstein, R.P. Anorexia nervosa, perfectionism, and dopamine D4 receptor (DRD4). Am. J. Med Genet. Part B Neuropsychiatr. Genet. Off. Publ. Int. Soc. Psychiatr. Genet. 2007, 144B, 748-756. [CrossRef] [PubMed]

27. Kaplan, A.S.; Levitan, R.D.; Yilmaz, Z.; Davis, C.; Tharmalingam, S.; Kennedy, J.L. A DRD4/BDNF gene-gene interaction associated with maximum BMI in women with bulimia nervosa. Int. J. Eat. Disord. 2008, 41, 22-28. [CrossRef]

28. Levitan, R.D.; Masellis, M.; Basile, V.S.; Lam, R.W.; Kaplan, A.S.; Davis, C.; Muglia, P.; Mackenzie, B.; Tharmalingam, S.; Kennedy, S.H.; et al. The dopamine-4 receptor gene associated with binge eating and weight gain in women with seasonal affective disorder: An evolutionary perspective. Biol. Psychiatry 2004, 56, 665-669. [CrossRef]

29. Levitan, R.D.; Masellis, M.; Lam, R.W.; Muglia, P.; Basile, V.S.; Jain, U.; Kaplan, A.S.; Tharmalingam, S.; Kennedy, S.H.; Kennedy, J.L. Childhood inattention and dysphoria and adult obesity associated with the dopamine D4 receptor gene in overeating women with seasonal affective disorder. Neuropsychopharmacol. Off. Publ. Am. Coll. Neuropsychopharmacol. 2004, 29, 179-186. [CrossRef]

30. Poston, W.S., 2nd; Ericsson, M.; Linder, J.; Haddock, C.K.; Hanis, C.L.; Nilsson, T.; Astrom, M.; Foreyt, J.P. D4 dopamine receptor gene exon III polymorphism and obesity risk. Eat. Weight. Disord. EWD 1998, 3, 71-77. [CrossRef]

31. Oak, J.N.; Oldenhof, J.; Van Tol, H.H. The dopamine D(4) receptor: One decade of research. Eur. J. Pharmacol. 2000, 405, 303-327. [CrossRef]

32. Asghari, V.; Sanyal, S.; Buchwaldt, S.; Paterson, A.; Jovanovic, V.; Van Tol, H.H. Modulation of intracellular cyclic AMP levels by different human dopamine D4 receptor variants. J. Neurochem. 1995, 65, 1157-1165. [CrossRef] [PubMed]

33. Lanau, F.; Zenner, M.T.; Civelli, O.; Hartman, D.S. Epinephrine and norepinephrine act as potent agonists at the recombinant human dopamine D4 receptor. J. Neurochem. 1997, 68, 804-812. [CrossRef] [PubMed]

34. Newman-Tancredi, A.; Audinot-Bouchez, V.; Gobert, A.; Millan, M.J. Noradrenaline and adrenaline are high affinity agonists at dopamine D4 receptors. Eur. J. Pharmacol. 1997, 319, 379-383. [CrossRef]

35. Matsumoto, M.; Hidaka, K.; Tada, S.; Tasaki, Y.; Yamaguchi, T. Full-length cDNA cloning and distribution of human dopamine D4 receptor. Brain Res. Mol. Brain Res. 1995, 29, 157-162. [CrossRef]

36. Valerio, A.; Belloni, M.; Gorno, M.L.; Tinti, C.; Memo, M.; Spano, P. Dopamine D2, D3, and D4 receptor mRNA levels in rat brain and pituitary during aging. Neurobiol. Aging 1994, 15, 713-719. [CrossRef]

37. Van Tol, H.H.; Bunzow, J.R.; Guan, H.C.; Sunahara, R.K.; Seeman, P.; Niznik, H.B.; Civelli, O. Cloning of the gene for a human dopamine D4 receptor with high affinity for the antipsychotic clozapine. Nature 1991, 350, 610-614. [CrossRef]

38. Lidow, M.S.; Wang, F.; Cao, Y.; Goldman-Rakic, P.S. Layer V neurons bear the majority of mRNAs encoding the five distinct dopamine receptor subtypes in the primate prefrontal cortex. Synapse 1998, 28, 10-20. [CrossRef]

39. Meador-Woodruff, J.H.; Grandy, D.K.; Van Tol, H.H.; Damask, S.P.; Little, K.Y.; Civelli, O.; Watson, S.J., Jr. Dopamine receptor gene expression in the human medial temporal lobe. Neuropsychopharmacol. Off. Publ. Am. Coll. Neuropsychopharmacol. 1994, 10, 239-248. [CrossRef]

40. Ariano, M.A.; Wang, J.; Noblett, K.L.; Larson, E.R.; Sibley, D.R. Cellular distribution of the rat D4 dopamine receptor protein in the CNS using anti-receptor antisera. Brain Res. 1997, 752, 26-34. [CrossRef]

41. Defagot, M.C.; Antonelli, M.C. Autoradiographic localization of the putative D4 dopamine receptor in rat brain. Neurochem. Res. 1997, 22, 401-407. [CrossRef] [PubMed] 
42. Khan, Z.U.; Gutierrez, A.; Martin, R.; Penafiel, A.; Rivera, A.; De La Calle, A. Differential regional and cellular distribution of dopamine D2-like receptors: An immunocytochemical study of subtype-specific antibodies in rat and human brain. J. Comp. Neurol. 1998, 402, 353-371. [CrossRef]

43. Mrzljak, L.; Bergson, C.; Pappy, M.; Huff, R.; Levenson, R.; Goldman-Rakic, P.S. Localization of dopamine D4 receptors in GABAergic neurons of the primate brain. Nature 1996, 381, 245-248. [CrossRef] [PubMed]

44. Rivera, A.; Cuellar, B.; Giron, F.J.; Grandy, D.K.; De la Calle, A.; Moratalla, R. Dopamine D4 receptors are heterogeneously distributed in the striosomes/matrix compartments of the striatum. J. Neurochem. 2002, 80, 219-229. [CrossRef] [PubMed]

45. Ricci, A.; Bronzetti, E.; Fedele, F.; Ferrante, F.; Zaccheo, D.; Amenta, F. Pharmacological characterization and autoradiographic localization of a putative dopamine D4 receptor in the heart. J. Auton. Pharmacol. 1998, 18, 115-121. [CrossRef] [PubMed]

46. Bondy, B.; De Jonge, S.; Pander, S.; Primbs, J.; Ackenheil, M. Identification of dopamine D4 receptor mRNA in circulating human lymphocytes using nested polymerase chain reaction. J. Neuroimmunol. 1996, 71, 139-144. [CrossRef]

47. Sun, D.; Wilborn, T.W.; Schafer, J.A. Dopamine D4 receptor isoform mRNA and protein are expressed in the rat cortical collecting duct. Am. J. Physiol. 1998, 275, F742-F751. [CrossRef]

48. Primus, R.J.; Thurkauf, A.; Xu, J.; Yevich, E.; McInerney, S.; Shaw, K.; Tallman, J.F.; Gallagher, D.W., II. Localization and characterization of dopamine D4 binding sites in rat and human brain by use of the novel, D4 receptor-selective ligand [3H]NGD 94-1. Pharmacol. Exp. Ther. 1997, 282, 1020-1027.

49. Goldman-Rakic, P.S. Cellular basis of working memory. Neuron 1995, 14, 477-485. [CrossRef]

50. Miller, E.K.; Cohen, J.D. An integrative theory of prefrontal cortex function. Annu. Rev. Neurosci. 2001, 24, 167-202. [CrossRef]

51. Lauzon, N.M.; Laviolette, S.R. Dopamine D4-receptor modulation of cortical neuronal network activity and emotional processing: Implications for neuropsychiatric disorders. Behav. Brain Res. 2010, 208, 12-22. [CrossRef] [PubMed]

52. Svingos, A.L.; Periasamy, S.; Pickel, V.M. Dopamine D4 receptors are strategically localized for primary involvement in the presynaptic effects of dopamine in the rat nucleus accumbens shell. Ann. N. Y. Acad. Sci. 1999, 877, 679-683. [CrossRef] [PubMed]

53. Tarazi, F.I.; Campbell, A.; Yeghiayan, S.K.; Baldessarini, R.J. Localization of dopamine receptor subtypes in corpus striatum and nucleus accumbens septi of rat brain: Comparison of D1-, D2-, and D4-like receptors. Neuroscience 1998, 83, 169-176. [CrossRef]

54. Bonaventura, J.; Quiroz, C.; Cai, N.S.; Rubinstein, M.; Tanda, G.; Ferre, S. Key role of the dopamine D4 receptor in the modulation of corticostriatal glutamatergic neurotransmission. Sci. Adv. 2017, 3, e1601631. [CrossRef]

55. Rubinstein, M.; Cepeda, C.; Hurst, R.S.; Flores-Hernandez, J.; Ariano, M.A.; Falzone, T.L.; Kozell, L.B.; Meshul, C.K.; Bunzow, J.R.; Low, M.J.; et al. Dopamine D4 receptor-deficient mice display cortical hyperexcitability. J. Neurosci. Off. J. Soc. Neurosci. 2001, 21, 3756-3763. [CrossRef]

56. Falzone, T.L.; Gelman, D.M.; Young, J.I.; Grandy, D.K.; Low, M.J.; Rubinstein, M. Absence of dopamine D4 receptors results in enhanced reactivity to unconditioned, but not conditioned, fear. Eur. J. Neurosci. 2002, 15, 158-164. [CrossRef]

57. Wise, R.A. Roles for nigrostriatal-not just mesocorticolimbic-dopamine in reward and addiction. Trends Neurosci. 2009, 32, 517-524. [CrossRef]

58. Di Chiara, G.; Imperato, A. Drugs abused by humans preferentially increase synaptic dopamine concentrations in the mesolimbic system of freely moving rats. Proc. Natl. Acad. Sci. USA 1988, 85, 5274-5278. [CrossRef]

59. Volkow, N.D.; Fowler, J.S.; Wang, G.J.; Baler, R.; Telang, F. Imaging dopamine's role in drug abuse and addiction. Neuropharmacology 2009, 56 (Suppl. 1), 3-8. [CrossRef]

60. McClure, S.M.; Daw, N.D.; Montague, P.R. A computational substrate for incentive salience. Trends Neurosci. 2003, 26, 423-428. [CrossRef]

61. Berridge, K.C.; Robinson, T.E. What is the role of dopamine in reward: Hedonic impact, reward learning, or incentive salience? Brain Res. Brain Res. Rev. 1998, 28, 309-369. [CrossRef]

62. Volkow, N.D.; Wang, G.J.; Fowler, J.S.; Tomasi, D.; Telang, F.; Baler, R. Addiction: Decreased reward sensitivity and increased expectation sensitivity conspire to overwhelm the brain's control circuit. Bioessays 2010, 32, 748-755. [CrossRef] [PubMed] 
63. Volkow, N.D.; Wang, G.J.; Fowler, J.S.; Tomasi, D. Addiction circuitry in the human brain. Annu Rev. Pharmacol. Toxicol. 2012, 52, 321-336. [CrossRef] [PubMed]

64. Tang, Y.Y.; Posner, M.I.; Rothbart, M.K.; Volkow, N.D. Circuitry of self-control and its role in reducing addiction. Trends Cogn. Sci. 2015, 19, 439-444. [CrossRef]

65. Murray, E.A.; Rudebeck, P.H. Specializations for reward-guided decision-making in the primate ventral prefrontal cortex. Nat. Rev. Neurosci. 2018, 19, 404-417. [CrossRef]

66. Chau, B.K.H.; Jarvis, H.; Law, C.K.; Chong, T.T. Dopamine and reward: A view from the prefrontal cortex. Behav. Pharmacol. 2018, 29, 569-583. [CrossRef]

67. Geisler, S.; Wise, R.A. Functional implications of glutamatergic projections to the ventral tegmental area. Rev. Neurosci. 2008, 19, 227-244. [CrossRef]

68. Koob, G.F.; Volkow, N.D. Neurobiology of addiction: A neurocircuitry analysis. Lancet Psychiatry 2016, 3, 760-773. [CrossRef]

69. Volkow, N.D.; Morales, M. The Brain on Drugs: From Reward to Addiction. Cell 2015, 162, $712-725$. [CrossRef]

70. Ceci, A.; Brambilla, A.; Duranti, P.; Grauert, M.; Grippa, N.; Borsini, F. Effect of antipsychotic drugs and selective dopaminergic antagonists on dopamine-induced facilitatory activity in prelimbic cortical pyramidal neurons. An In Vitro study. Neuroscience 1999, 93, 107-115. [CrossRef]

71. Floresco, S.B.; Tse, M.T. Dopaminergic regulation of inhibitory and excitatory transmission in the basolateral amygdala-prefrontal cortical pathway. J. Neurosci. Off. J. Soc. Neurosci. 2007, 27, 2045-2057. [CrossRef]

72. Lauzon, N.M.; Bishop, S.F.; Laviolette, S.R. Dopamine D1 versus D4 receptors differentially modulate the encoding of salient versus nonsalient emotional information in the medial prefrontal cortex. J. Neurosci. Off. J. Soc. Neurosci. 2009, 29, 4836-4845. [CrossRef]

73. Laviolette, S.R.; Lipski, W.J.; Grace, A.A. A subpopulation of neurons in the medial prefrontal cortex encodes emotional learning with burst and frequency codes through a dopamine D4 receptor-dependent basolateral amygdala input. J. Neurosci. Off. J. Soc. Neurosci. 2005, 25, 6066-6075. [CrossRef]

74. Noain, D.; Avale, M.E.; Wedemeyer, C.; Calvo, D.; Peper, M.; Rubinstein, M. Identification of brain neurons expressing the dopamine D4 receptor gene using BAC transgenic mice. Eur. J. Neurosci. 2006, 24, 2429-2438. [CrossRef]

75. Ptacek, R.; Kuzelova, H.; Stefano, G.B. Dopamine D4 receptor gene DRD4 and its association with psychiatric disorders. Med. Sci. Monit. 2011, 17, RA215-RA220. [CrossRef]

76. Mallard, T.T.; Doorley, J.; Esposito-Smythers, C.L.; McGeary, J.E. Dopamine D4 receptor VNTR polymorphism associated with greater risk for substance abuse among adolescents with disruptive behavior disorders: Preliminary results. Am. J. Addict. 2016, 25, 56-61. [CrossRef]

77. McGeary, J. The DRD4 exon 3 VNTR polymorphism and addiction-related phenotypes: A review. Pharmacol. Biochem. Behav. 2009, 93, 222-229. [CrossRef]

78. Patriquin, M.A.; Bauer, I.E.; Soares, J.C.; Graham, D.P.; Nielsen, D.A. Addiction pharmacogenetics: A systematic review of the genetic variation of the dopaminergic system. Psychiatr. Genet. 2015, 25, 181-193. [CrossRef]

79. Hutchison, K.E.; McGeary, J.; Smolen, A.; Bryan, A.; Swift, R.M. The DRD4 VNTR polymorphism moderates craving after alcohol consumption. Health Psychol. 2002, 21, 139-146. [CrossRef]

80. Hutchison, K.E.; Ray, L.; Sandman, E.; Rutter, M.C.; Peters, A.; Davidson, D.; Swift, R. The effect of olanzapine on craving and alcohol consumption. Neuropsychopharmacol. Off. Publ. Am. College Neuropsychopharmacol. 2006, 31, 1310-1317. [CrossRef]

81. Hutchison, K.E.; Wooden, A.; Swift, R.M.; Smolen, A.; McGeary, J.; Adler, L.; Paris, L. Olanzapine reduces craving for alcohol: A DRD4 VNTR polymorphism by pharmacotherapy interaction. Neuropsychopharmacol. Off. Publ. Am. College Neuropsychopharmacol. 2003, 28, 1882-1888. [CrossRef] [PubMed]

82. Liang, J.; Olsen, R.W. Alcohol use disorders and current pharmacological therapies: The role of GABA(A) receptors. Acta Pharmacol. Sin. 2014, 35, 981-993. [CrossRef] [PubMed]

83. Miranda, R., Jr.; Treloar Padovano, H.; Gray, J.C.; Wemm, S.E.; Blanchard, A. Real-time assessment of alcohol craving and naltrexone treatment responsiveness in a randomized clinical trial. Addict. Behav. 2018, 83, 72-78. [CrossRef] [PubMed] 
84. Tidey, J.W.; Monti, P.M.; Rohsenow, D.J.; Gwaltney, C.J.; Miranda, R., Jr.; McGeary, J.E.; MacKillop, J.; Swift, R.M.; Abrams, D.B.; Shiffman, S.; et al. Moderators of naltrexone's effects on drinking, urge, and alcohol effects in non-treatment-seeking heavy drinkers in the natural environment. Alcohol. Clin. Exp. Res. 2008, 32, 58-66. [CrossRef] [PubMed]

85. Filbey, F.M.; Ray, L.; Smolen, A.; Claus, E.D.; Audette, A.; Hutchison, K.E. Differential neural response to alcohol priming and alcohol taste cues is associated with DRD4 VNTR and OPRM1 genotypes. Alcohol. Clin. Exp. Res. 2008, 32, 1113-1123. [CrossRef]

86. Laucht, M.; Becker, K.; Blomeyer, D.; Schmidt, M.H. Novelty seeking involved in mediating the association between the dopamine D4 receptor gene exon III polymorphism and heavy drinking in male adolescents: Results from a high-risk community sample. Biol. Psychiatry 2007, 61, 87-92. [CrossRef]

87. Ray, L.A.; Bryan, A.; Mackillop, J.; McGeary, J.; Hesterberg, K.; Hutchison, K.E. The dopamine D Receptor (DRD4) gene exon III polymorphism, problematic alcohol use and novelty seeking: Direct and mediated genetic effects. Addict. Biol. 2009, 14, 238-244. [CrossRef]

88. Laucht, M.; Becker, K.; El-Faddagh, M.; Hohm, E.; Schmidt, M.H. Association of the DRD4 exon III polymorphism with smoking in fifteen-year-olds: A mediating role for novelty seeking? J. Am. Acad. Child Adolesc. Psychiatry 2005, 44, 477-484. [CrossRef]

89. Mackillop, J.; Menges, D.P.; McGeary, J.E.; Lisman, S.A. Effects of craving and DRD4 VNTR genotype on the relative value of alcohol: An initial human laboratory study. Behav. Brain Funct. 2007, 3, 11. [CrossRef]

90. Van den Wildenberg, E.; Janssen, R.G.; Hutchison, K.E.; Van Breukelen, G.J.; Wiers, R.W. Polymorphisms of the dopamine D4 receptor gene (DRD4 VNTR) and cannabinoid CB1 receptor gene (CNR1) are not strongly related to cue-reactivity after alcohol exposure. Addict. Biol. 2007, 12, 210-220. [CrossRef]

91. Shields, P.G.; Lerman, C.; Audrain, J.; Bowman, E.D.; Main, D.; Boyd, N.R.; Caporaso, N.E. Dopamine D4 receptors and the risk of cigarette smoking in African-Americans and Caucasians. Cancer Epidemiol. Biomark. Prev. 1998, 7, 453-458.

92. McClernon, F.J.; Hutchison, K.E.; Rose, J.E.; Kozink, R.V. DRD4 VNTR polymorphism is associated with transient fMRI-BOLD responses to smoking cues. Psychopharmacology 2007, 194, 433-441. [CrossRef] [PubMed]

93. Hutchison, K.E.; LaChance, H.; Niaura, R.; Bryan, A.; Smolen, A. The DRD4 VNTR polymorphism influences reactivity to smoking cues. J. Abnorm. Psychol. 2002, 111, 134-143. [CrossRef] [PubMed]

94. Brody, A.L.; Mandelkern, M.A.; Olmstead, R.E.; Scheibal, D.; Hahn, E.; Shiraga, S.; Zamora-Paja, E.; Farahi, J.; Saxena, S.; London, E.D.; et al. Gene variants of brain dopamine pathways and smoking-induced dopamine release in the ventral caudate/nucleus accumbens. Arch. Gen. Psychiatry 2006, 63, 808-816. [CrossRef] [PubMed]

95. David, S.P.; Munafo, M.R.; Murphy, M.F.; Proctor, M.; Walton, R.T.; Johnstone, E.C. Genetic variation in the dopamine D4 receptor (DRD4) gene and smoking cessation: Follow-up of a randomised clinical trial of transdermal nicotine patch. Pharm. J. 2008, 8, 122-128. [CrossRef]

96. Ton, T.G.; Rossing, M.A.; Bowen, D.J.; Srinouanprachan, S.; Wicklund, K.; Farin, F.M. Genetic polymorphisms in dopamine-related genes and smoking cessation in women: A prospective cohort study. Behav. Brain Funct. 2007, 3, 22. [CrossRef]

97. Munafo, M.R.; Johnstone, E.C. Smoking status moderates the association of the dopamine D4 receptor (DRD4) gene VNTR polymorphism with selective processing of smoking-related cues. Addict. Biol. 2008, 13, 435-439. [CrossRef]

98. Shao, C.; Li, Y.; Jiang, K.; Zhang, D.; Xu, Y.; Lin, L.; Wang, Q.; Zhao, M.; Jin, L. Dopamine D4 receptor polymorphism modulates cue-elicited heroin craving in Chinese. Psychopharmacology 2006, 186, 185-190. [CrossRef]

99. Kotler, M.; Cohen, H.; Segman, R.; Gritsenko, I.; Nemanov, L.; Lerer, B.; Kramer, I.; Zer-Zion, M.; Kletz, I.; Ebstein, R.P. Excess dopamine D4 receptor (D4DR) exon III seven repeat allele in opioid-dependent subjects. Mol. Psychiatry 1997, 2, 251-254. [CrossRef]

100. Chen, D.; Liu, F.; Shang, Q.; Song, X.; Miao, X.; Wang, Z. Association between polymorphisms of DRD2 and DRD4 and opioid dependence: Evidence from the current studies. Am. J. Med Genet. Part. B Neuropsychiatr. Genet. Off. Publ. Int. Soc. Psychiatr. Genet. 2011, 156B, 661-670. [CrossRef] 
101. Chen, C.K.; Hu, X.; Lin, S.K.; Sham, P.C.; Loh el, W.; Li, T.; Murray, R.M.; Ball, D.M. Association analysis of dopamine D2-like receptor genes and methamphetamine abuse. Psychiatr. Genet. 2004, 14, 223-226. [CrossRef]

102. Tsai, S.J.; Cheng, C.Y.; Shu, L.R.; Yang, C.Y.; Pan, C.W.; Liou, Y.J.; Hong, C.J. No association for D2 and D4 dopamine receptor polymorphisms and methamphetamine abuse in Chinese males. Psychiatr. Genet. 2002, 12, 29-33. [CrossRef]

103. Comings, D.E.; Blum, K. Reward deficiency syndrome: Genetic aspects of behavioral disorders. Prog. Brain Res. 2000, 126, 325-341. [CrossRef] [PubMed]

104. Rubinstein, M.; Phillips, T.J.; Bunzow, J.R.; Falzone, T.L.; Dziewczapolski, G.; Zhang, G.; Fang, Y.; Larson, J.L.; McDougall, J.A.; Chester, J.A.; et al. Mice lacking dopamine D4 receptors are supersensitive to ethanol, cocaine, and methamphetamine. Cell 1997, 90, 991-1001. [CrossRef]

105. Wise, R.A.; Bozarth, M.A. A psychomotor stimulant theory of addiction. Psychol. Rev. 1987, 94, 469-492. [CrossRef] [PubMed]

106. Katz, J.L.; Chausmer, A.L.; Elmer, G.I.; Rubinstein, M.; Low, M.J.; Grandy, D.K. Cocaine-induced locomotor activity and cocaine discrimination in dopamine D4 receptor mutant mice. Psychopharmacology 2003, 170, 108-114. [CrossRef]

107. Keck, T.M.; Suchland, K.L.; Jimenez, C.C.; Grandy, D.K. Dopamine D4 receptor deficiency in mice alters behavioral responses to anxiogenic stimuli and the psychostimulant methylphenidate. Pharmacol. Biochem. Behav. 2013, 103, 831-841. [CrossRef] [PubMed]

108. Kruzich, P.J.; Suchland, K.L.; Grandy, D.K. Dopamine D4 receptor-deficient mice, congenic on the C57BL/6J background, are hypersensitive to amphetamine. Synapse 2004, 53, 131-139. [CrossRef] [PubMed]

109. Thanos, P.K.; Bermeo, C.; Rubinstein, M.; Suchland, K.L.; Wang, G.J.; Grandy, D.K.; Volkow, N.D. Conditioned place preference and locomotor activity in response to methylphenidate, amphetamine and cocaine in mice lacking dopamine D4 receptors. J. Psychopharmacol. 2010, 24, 897-904. [CrossRef]

110. Prus, A.J.; James, J.R.; Rosecrans, J.A. Conditioned Place Preference. In Methods of Behavior Analysis in Neuroscience, 2nd ed.; Buccafusco, J.J., Ed.; CRC Press/Taylor \& Francis: Boca Raton, FL, USA.

111. Ananth, M.; Hetelekides, E.M.; Hamilton, J.; Thanos, P.K. Dopamine D4 receptor gene expression plays important role in extinction and reinstatement of cocaine-seeking behavior in mice. Behav. Brain Res. 2019, 365, 1-6. [CrossRef]

112. Belin, D.; Deroche-Gamonet, V. Responses to novelty and vulnerability to cocaine addiction: Contribution of a multi-symptomatic animal model. Cold Spring Harb. Perspect. Med. 2012, 2. [CrossRef] [PubMed]

113. Blanchard, M.M.; Mendelsohn, D.; Stamp, J.A. The HR/LR model: Further evidence as an animal model of sensation seeking. Neurosci. Biobehav. Rev. 2009, 33, 1145-1154. [CrossRef]

114. Piazza, P.V.; Deminiere, J.M.; Le Moal, M.; Simon, H. Factors that predict individual vulnerability to amphetamine self-administration. Science 1989, 245, 1511-1513. [CrossRef]

115. Dulawa, S.C.; Grandy, D.K.; Low, M.J.; Paulus, M.P.; Geyer, M.A. Dopamine D4 receptor-knock-out mice exhibit reduced exploration of novel stimuli. J. Neurosci. Off. J. Soc. Neurosci. 1999, 19, 9550-9556. [CrossRef]

116. Powell, S.B.; Paulus, M.P.; Hartman, D.S.; Godel, T.; Geyer, M.A. RO-10-5824 is a selective dopamine D4 receptor agonist that increases novel object exploration in C57 mice. Neuropharmacology 2003, 44, 473-481. [CrossRef]

117. Helms, C.M.; Gubner, N.R.; Wilhelm, C.J.; Mitchell, S.H.; Grandy, D.K. D4 receptor deficiency in mice has limited effects on impulsivity and novelty seeking. Pharmacol. Biochem. Behav. 2008, 90, 387-393. [CrossRef]

118. Thanos, P.K.; Roushdy, K.; Sarwar, Z.; Rice, O.; Ashby, C.R., Jr.; Grandy, D.K. The effect of dopamine D4 receptor density on novelty seeking, activity, social interaction, and alcohol binge drinking in adult mice. Synapse 2015, 69, 356-364. [CrossRef] [PubMed]

119. Roozen, H.G.; Wetering, B.J.; Franken, I.H. Does alcohol craving mediate the impulsivity-aggression relationship in recently detoxified alcohol-dependent patients? Am. J. Drug Alcohol Abus. 2013, 39, 57-60. [CrossRef]

120. Gan, L.; Falzone, T.L.; Zhang, K.; Rubinstein, M.; Baldessarini, R.J.; Tarazi, F.I. Enhanced expression of dopamine $\mathrm{D}(1)$ and glutamate NMDA receptors in dopamine $\mathrm{D}(4)$ receptor knockout mice. J. Mol. Neurosci. MN 2004, 22, 167-178. [CrossRef] 
121. Kulagowski, J.J.; Broughton, H.B.; Curtis, N.R.; Mawer, I.M.; Ridgill, M.P.; Baker, R.; Emms, F.; Freedman, S.B.; Marwood, R.; Patel, S.; et al. 3-((4-(4-Chlorophenyl)piperazin-1-yl)-methyl)-1H-pyrrolo-2,3-b-pyridine: An antagonist with high affinity and selectivity for the human dopamine D4 receptor. J. Med. Chem. 1996, 39, 1941-1942. [CrossRef]

122. Patel, S.; Freedman, S.; Chapman, K.L.; Emms, F.; Fletcher, A.E.; Knowles, M.; Marwood, R.; McAllister, G.; Myers, J.; Curtis, N.; et al. Biological profile of L-745,870, a selective antagonist with high affinity for the dopamine D4 receptor. J. Pharmacol. Exp. Ther. 1997, 283, 636-647. [PubMed]

123. Caine, S.B.; Negus, S.S.; Mello, N.K.; Patel, S.; Bristow, L.; Kulagowski, J.; Vallone, D.; Saiardi, A.; Borrelli, E. Role of dopamine D2-like receptors in cocaine self-administration: Studies with D2 receptor mutant mice and novel D2 receptor antagonists. J. Neurosci. Off. J. Soc. Neurosci. 2002, 22, 2977-2988. [CrossRef]

124. Costanza, R.M.; Terry, P. The dopamine D4 receptor antagonist L-745,870: Effects in rats discriminating cocaine from saline. Eur. J. Pharmacol. 1998, 345, 129-132. [CrossRef]

125. Yan, Y.; Mizuno, T.; Nitta, A.; Yamada, K.; Nabeshima, T. Nefiracetam attenuates methamphetamine-induced discriminative stimulus effects in rats. Ann. N. Y. Acad. Sci. 2004, 1025, 274-278. [CrossRef] [PubMed]

126. Yan, Y.; Nitta, A.; Mizuno, T.; Nakajima, A.; Yamada, K.; Nabeshima, T. Discriminative-stimulus effects of methamphetamine and morphine in rats are attenuated by cAMP-related compounds. Behav. Brain Res. 2006, 173, 39-46. [CrossRef] [PubMed]

127. Mamiya, T.; Matsumura, T.; Ukai, M. Effects of L-745,870, a dopamine D4 receptor antagonist, on naloxone-induced morphine dependence in mice. Ann. N. Y. Acad. Sci. 2004, 1025, 424-429. [CrossRef]

128. Kim, A.; Di Ciano, P.; Pushparaj, A.; Leca, J.; Le Foll, B. The effects of dopamine D4 receptor ligands on operant alcohol self-administration and cue- and stress-induced reinstatement in rats. Eur. J. Pharmacol. 2020, 867, 172838. [CrossRef]

129. Yan, Y.; Pushparaj, A.; Le Strat, Y.; Gamaleddin, I.; Barnes, C.; Justinova, Z.; Goldberg, S.R.; Le Foll, B. Blockade of dopamine $\mathrm{d} 4$ receptors attenuates reinstatement of extinguished nicotine-seeking behavior in rats. Neuropsychopharmacol. Off. Publ. Am. College Neuropsychopharmacol. 2012, 37, 685-696. [CrossRef]

130. Forget, B.; Pushparaj, A.; Le Foll, B. Granular insular cortex inactivation as a novel therapeutic strategy for nicotine addiction. Biol. Psychiatry 2010, 68, 265-271. [CrossRef]

131. Naqvi, N.H.; Rudrauf, D.; Damasio, H.; Bechara, A. Damage to the insula disrupts addiction to cigarette smoking. Science 2007, 315, 531-534. [CrossRef]

132. Patel, S.; Patel, S.; Marwood, R.; Emms, F.; Marston, D.; Leeson, P.D.; Curtis, N.R.; Kulagowski, J.J.; Freedman, S.B. Identification and pharmacological characterization of [125I]L-750,667, a novel radioligand for the dopamine D4 receptor. Mol. Pharmacol. 1996, 50, 1658-1664.

133. Anderson, S.M.; Schmidt, H.D.; Pierce, R.C. Administration of the D2 dopamine receptor antagonist sulpiride into the shell, but not the core, of the nucleus accumbens attenuates cocaine priming-induced reinstatement of drug seeking. Neuropsychopharmacol. Off. Publ. Am. College Neuropsychopharmacol. 2006, 31, 1452-1461. [CrossRef]

134. Feldpausch, D.L.; Needham, L.M.; Stone, M.P.; Althaus, J.S.; Yamamoto, B.K.; Svensson, K.A.; Merchant, K.M. The role of dopamine D4 receptor in the induction of behavioral sensitization to amphetamine and accompanying biochemical and molecular adaptations. J. Pharmacol. Exp. Ther. 1998, 286, 497-508. [PubMed]

135. Glase, S.A.; Akunne, H.C.; Georgic, L.M.; Heffner, T.G.; MacKenzie, R.G.; Manley, P.J.; Pugsley, T.A.; Wise, L.D. Substituted [(4-phenylpiperazinyl)-methyl]benzamides: Selective dopamine D4 agonists. J. Med. Chem. 1997, 40, 1771-1772. [CrossRef] [PubMed]

136. Moreland, R.B.; Patel, M.; Hsieh, G.C.; Wetter, J.M.; Marsh, K.; Brioni, J.D. A-412997 is a selective dopamine D4 receptor agonist in rats. Pharmacol. Biochem. Behav. 2005, 82, 140-147. [CrossRef] [PubMed]

137. Rivera, A.; Gago, B.; Suarez-Boomgaard, D.; Yoshitake, T.; Roales-Bujan, R.; Valderrama-Carvajal, A.; Bilbao, A.; Medina-Luque, J.; Diaz-Cabiale, Z.; Craenenbroeck, K.V.; et al. Dopamine D4 receptor stimulation prevents nigrostriatal dopamine pathway activation by morphine: Relevance for drug addiction. Addict. Biol. 2017, 22, 1232-1245. [CrossRef] [PubMed]

138. Fuxe, K.; Marcellino, D.; Rivera, A.; Diaz-Cabiale, Z.; Filip, M.; Gago, B.; Roberts, D.C.; Langel, U.; Genedani, S.; Ferraro, L.; et al. Receptor-receptor interactions within receptor mosaics. Impact on neuropsychopharmacology. Brain Res. Rev. 2008, 58, 415-452. [CrossRef] 
139. Rivera, A.; Trias, S.; Penafiel, A.; Angel Narvaez, J.; Diaz-Cabiale, Z.; Moratalla, R.; De la Calle, A. Expression of D4 dopamine receptors in striatonigral and striatopallidal neurons in the rat striatum. Brain Res. 2003, 989, 35-41. [CrossRef]

140. Gago, B.; Fuxe, K.; Brene, S.; Diaz-Cabiale, Z.; Reina-Sanchez, M.D.; Suarez-Boomgaard, D.; Roales-Bujan, R.; Valderrama-Carvajal, A.; De la Calle, A.; Rivera, A. Early modulation by the dopamine D4 receptor of morphine-induced changes in the opioid peptide systems in the rat caudate putamen. J. Neurosci. Res. 2013, 91, 1533-1540. [CrossRef]

141. Gago, B.; Suarez-Boomgaard, D.; Fuxe, K.; Brene, S.; Reina-Sanchez, M.D.; Rodriguez-Perez, L.M.; Agnati, L.F.; De la Calle, A.; Rivera, A. Effect of acute and continuous morphine treatment on transcription factor expression in subregions of the rat caudate putamen. Marked modulation by D4 receptor activation. Brain Res. 2011, 1407, 47-61. [CrossRef]

142. Negrete-Diaz, J.V.; Shumilov, K.; Real, M.A.; Medina-Luque, J.; Valderrama-Carvajal, A.; Flores, G.; Rodriguez-Moreno, A.; Rivera, A. Pharmacological activation of dopamine D4 receptor modulates morphine-induced changes in the expression of GAD65/67 and GABAB receptors in the basal ganglia. Neuropharmacology 2019, 152, 22-29. [CrossRef] [PubMed]

143. Suarez-Boomgaard, D.; Gago, B.; Valderrama-Carvajal, A.; Roales-Bujan, R.; Van Craenenbroeck, K.; Duchou, J.; Borroto-Escuela, D.O.; Medina-Luque, J.; De la Calle, A.; Fuxe, K.; et al. Dopamine D(4) receptor counteracts morphine-induced changes in micro opioid receptor signaling in the striosomes of the rat caudate putamen. Int. J. Mol. Sci. 2014, 15, 1481-1498. [CrossRef] [PubMed]

144. Koffarnus, M.N.; Collins, G.T.; Rice, K.C.; Chen, J.; Woods, J.H.; Winger, G. Self-administration of agonists selective for dopamine D2, D3, and D4 receptors by rhesus monkeys. Behav. Pharmacol. 2012, 23, 331-338. [CrossRef] [PubMed]

145. Woolley, M.L.; Waters, K.A.; Reavill, C.; Bull, S.; Lacroix, L.P.; Martyn, A.J.; Hutcheson, D.M.; Valerio, E.; Bate, S.; Jones, D.N.; et al. Selective dopamine D4 receptor agonist (A-412997) improves cognitive performance and stimulates motor activity without influencing reward-related behaviour in rat. Behav. Pharmacol. 2008, 19, 765-776. [CrossRef]

146. Sobik, L.; Hutchison, K.; Craighead, L. Cue-elicited craving for food: A fresh approach to the study of binge eating. Appetite 2005, 44, 253-261. [CrossRef]

147. Avena, N.M.; Bocarsly, M.E.; Hoebel, B.G.; Gold, M.S. Overlaps in the nosology of substance abuse and overeating: The translational implications of "food addiction". Curr. Drug Abus. Rev. 2011, 4, 133-139. [CrossRef]

148. D'Addario, C.; Micioni Di Bonaventura, M.V.; Pucci, M.; Romano, A.; Gaetani, S.; Ciccocioppo, R.; Cifani, C.; Maccarrone, M. Endocannabinoid signaling and food addiction. Neurosci. Biobehav. Rev. 2014, 47, $203-224$. [CrossRef]

149. Kenny, P.J.; Voren, G.; Johnson, P.M. Dopamine D2 receptors and striatopallidal transmission in addiction and obesity. Curr. Opin. Neurobiol. 2013, 23, 535-538. [CrossRef]

150. Volkow, N.D.; Fowler, J.S.; Wang, G.J.; Swanson, J.M. Dopamine in drug abuse and addiction: Results from imaging studies and treatment implications. Mol. Psychiatry 2004, 9, 557-569. [CrossRef]

151. Volkow, N.D.; Wise, R.A. How can drug addiction help us understand obesity? Nat. Neurosci. 2005, 8, 555-560. [CrossRef]

152. Hernandez, L.; Hoebel, B.G. Feeding can enhance dopamine turnover in the prefrontal cortex. Brain Res. Bull. 1990, 25, 975-979. [CrossRef]

153. Gabbott, P.L.; Warner, T.A.; Jays, P.R.; Salway, P.; Busby, S.J. Prefrontal cortex in the rat: Projections to subcortical autonomic, motor, and limbic centers. J. Comp. Neurol. 2005, 492, 145-177. [CrossRef] [PubMed]

154. Vertes, R.P. Differential projections of the infralimbic and prelimbic cortex in the rat. Synapse 2004, 51, 32-58. [CrossRef] [PubMed]

155. Inoue, K.; Kiriike, N.; Okuno, M.; Fujisaki, Y.; Kurioka, M.; Iwasaki, S.; Yamagami, S. Prefrontal and striatal dopamine metabolism during enhanced rebound hyperphagia induced by space restriction-a rat model of binge eating. Biol. Psychiatry 1998, 44, 1329-1336. [CrossRef]

156. Goldstein, R.Z.; Volkow, N.D. Dysfunction of the prefrontal cortex in addiction: Neuroimaging findings and clinical implications. Nat. Rev. Neurosci. 2011, 12, 652-669. [CrossRef]

157. Gluck, M.E.; Viswanath, P.; Stinson, E.J. Obesity, appetite, and the prefrontal cortex. Curr. Obes. Rep. 2017, 6, 380-388. [CrossRef] 
158. Micioni Di Bonaventura, M.V.; Martinelli, I.; Moruzzi, M.; Micioni Di Bonaventura, E.; Giusepponi, M.E.; Polidori, C.; Lupidi, G.; Tayebati, S.K.; Amenta, F.; Cifani, C.; et al. Brain alterations in high fat diet induced obesity: Effects of tart cherry seeds and juice. Nutrients 2020, 12, 0623. [CrossRef]

159. Tomassoni, D.; Martinelli, I.; Moruzzi, M.; Micioni Di Bonaventura, M.V.; Cifani, C.; Amenta, F.; Tayebati, S.K. Obesity and age-related changes in the brain of the Zucker Lepr (fa/fa) rats. Nutrients 2020, 12, 1356. [CrossRef]

160. Volkow, N.D.; Wang, G.J.; Telang, F.; Fowler, J.S.; Thanos, P.K.; Logan, J.; Alexoff, D.; Ding, Y.S.; Wong, C.; $\mathrm{Ma}, \mathrm{Y}$; et al. Low dopamine striatal D2 receptors are associated with prefrontal metabolism in obese subjects: Possible contributing factors. NeuroImage 2008, 42, 1537-1543. [CrossRef]

161. De Araujo, I.E.; Rolls, E.T.; Kringelbach, M.L.; McGlone, F.; Phillips, N. Taste-olfactory convergence, and the representation of the pleasantness of flavour, in the human brain. Eur. J. Neurosci. 2003, 18, 2059-2068. [CrossRef]

162. Felsted, J.A.; Ren, X.; Chouinard-Decorte, F.; Small, D.M. Genetically determined differences in brain response to a primary food reward. J. Neurosci. Off. J. Soc. Neurosci. 2010, 30, 2428-2432. [CrossRef] [PubMed]

163. Wang, G.J.; Volkow, N.D.; Telang, F.; Jayne, M.; Ma, J.; Rao, M.; Zhu, W.; Wong, C.T.; Pappas, N.R.; Geliebter, A.; et al. Exposure to appetitive food stimuli markedly activates the human brain. NeuroImage 2004, 21, 1790-1797. [CrossRef] [PubMed]

164. Cifani, C.; Koya, E.; Navarre, B.M.; Calu, D.J.; Baumann, M.H.; Marchant, N.J.; Liu, Q.R.; Khuc, T.; Pickel, J.; Lupica, C.R.; et al. Medial prefrontal cortex neuronal activation and synaptic alterations after stress-induced reinstatement of palatable food seeking: A study using c-fos-GFP transgenic female rats. J. Neurosci. Off. J. Soc. Neurosci. 2012, 32, 8480-8490. [CrossRef]

165. Nair, S.G.; Navarre, B.M.; Cifani, C.; Pickens, C.L.; Bossert, J.M.; Shaham, Y. Role of dorsal medial prefrontal cortex dopamine D1-family receptors in relapse to high-fat food seeking induced by the anxiogenic drug yohimbine. Neuropsychopharmacol. Off. Publ. Am. College Neuropsychopharmacol. 2011, 36, 497-510. [CrossRef]

166. Bedse, G.; Romano, A.; Tempesta, B.; Lavecchia, M.A.; Pace, L.; Bellomo, A.; Duranti, A.; Micioni Di Bonaventura, M.V.; Cifani, C.; Cassano, T.; et al. Inhibition of anandamide hydrolysis enhances noradrenergic and GABAergic transmission in the prefrontal cortex and basolateral amygdala of rats subjected to acute swim stress. J. Neurosci. Res. 2015, 93, 777-787. [CrossRef]

167. Radley, J.J.; Arias, C.M.; Sawchenko, P.E. Regional differentiation of the medial prefrontal cortex in regulating adaptive responses to acute emotional stress. J. Neurosci. Off. J. Soc. Neurosci. 2006, 26, 12967-12976. [CrossRef]

168. Jankord, R.; Herman, J.P. Limbic regulation of hypothalamo-pituitary-adrenocortical function during acute and chronic stress. Ann. N. Y. Acad. Sci. 2008, 1148, 64-73. [CrossRef]

169. Armbruster, D.; Mueller, A.; Moser, D.A.; Lesch, K.P.; Brocke, B.; Kirschbaum, C. Interaction effect of D4 dopamine receptor gene and serotonin transporter promoter polymorphism on the cortisol stress response. Behavioral Neurosci. 2009, 123, 1288-1295. [CrossRef]

170. Cifani, C.; Di Bonaventura, M.V.M.; Ciccocioppo, R.; Massi, M. Binge eating in female rats induced by yo-yo dieting and stress. In Animal Models of Eating Disorders; Springer, Humana Press: Totowa, NJ, USA, 2013; pp. 27-49.

171. Cifani, C.; Micioni Di, B.M.; Vitale, G.; Ruggieri, V.; Ciccocioppo, R.; Massi, M. Effect of salidroside, active principle of Rhodiola rosea extract, on binge eating. Physiol. Behav. 2010, 101, 555-562. [CrossRef]

172. Cifani, C.; Polidori, C.; Melotto, S.; Ciccocioppo, R.; Massi, M. A preclinical model of binge eating elicited by yo-yo dieting and stressful exposure to food: Effect of sibutramine, fluoxetine, topiramate, and midazolam. Psychopharmacology 2009, 204, 113-125. [CrossRef]

173. Coutinho, W.F.; Moreira, R.O.; Spagnol, C.; Appolinario, J.C. Does binge eating disorder alter cortisol secretion in obese women? Eat. Behav. 2007, 8, 59-64. [CrossRef] [PubMed]

174. Gluck, M.E.; Geliebter, A.; Lorence, M. Cortisol stress response is positively correlated with central obesity in obese women with binge eating disorder (BED) before and after cognitive-behavioral treatment. Ann. N. Y. Acad. Sci. 2004, 1032, 202-207. [CrossRef] [PubMed]

175. Micioni Di Bonaventura, M.V.; Vitale, G.; Massi, M.; Cifani, C. Effect of Hypericum perforatum Extract in an Experimental Model of Binge Eating in Female Rats. J. Obes. 2012, 2012, 956137. [CrossRef] [PubMed]

176. Epel, E.; Lapidus, R.; McEwen, B.; Brownell, K. Stress may add bite to appetite in women: A laboratory study of stress-induced cortisol and eating behavior. Psychoneuroendocrinology 2001, 26, 37-49. [CrossRef] 
177. Cottone, P.; Sabino, V.; Roberto, M.; Bajo, M.; Pockros, L.; Frihauf, J.B.; Fekete, E.M.; Steardo, L.; Rice, K.C.; Grigoriadis, D.E.; et al. CRF system recruitment mediates dark side of compulsive eating. Proc. Natl. Acad. Sci. USA 2009, 106, 20016-20020. [CrossRef] [PubMed]

178. Epstein, D.H.; Kennedy, A.P.; Furnari, M.; Heilig, M.; Shaham, Y.; Phillips, K.A.; Preston, K.L. Effect of the CRF1-receptor antagonist pexacerfont on stress-induced eating and food craving. Psychopharmacology 2016, 233, 3921-3932. [CrossRef]

179. Iemolo, A.; Blasio, A.; St Cyr, S.A.; Jiang, F.; Rice, K.C.; Sabino, V.; Cottone, P. CRF-CRF1 receptor system in the central and basolateral nuclei of the amygdala differentially mediates excessive eating of palatable food. Neuropsychopharmacol. Off. Publ. Am. College Neuropsychopharmacol. 2013, 38, 2456-2466. [CrossRef]

180. Micioni Di Bonaventura, M.V.; Ciccocioppo, R.; Romano, A.; Bossert, J.M.; Rice, K.C.; Ubaldi, M.; St Laurent, R.; Gaetani, S.; Massi, M.; Shaham, Y.; et al. Role of bed nucleus of the stria terminalis corticotrophin-releasing factor receptors in frustration stress-induced binge-like palatable food consumption in female rats with a history of food restriction. J. Neurosci. Off. J. Soc. Neurosci. 2014, 34, 11316-11324. [CrossRef]

181. Micioni Di Bonaventura, M.V.; Ubaldi, M.; Giusepponi, M.E.; Rice, K.C.; Massi, M.; Ciccocioppo, R.; Cifani, C. Hypothalamic CRF1 receptor mechanisms are not sufficient to account for binge-like palatable food consumption in female rats. Int. J. Eat. Disord. 2017, 50, 1194-1204. [CrossRef]

182. Parylak, S.L.; Cottone, P.; Sabino, V.; Rice, K.C.; Zorrilla, E.P. Effects of CB1 and CRF1 receptor antagonists on binge-like eating in rats with limited access to a sweet fat diet: Lack of withdrawal-like responses. Physiol. Behav. 2012, 107, 231-242. [CrossRef]

183. Pucci, M.; Micioni Di Bonaventura, M.V.; Giusepponi, M.E.; Romano, A.; Filaferro, M.; Maccarrone, M.; Ciccocioppo, R.; Cifani, C.; D'Addario, C. Epigenetic regulation of nociceptin/orphanin FQ and corticotropinreleasing factor system genes in frustration stress-induced binge-like palatable food consumption. Addict. Biol. 2016, 21, 1168-1185. [CrossRef] [PubMed]

184. Romano, A.; Micioni Di Bonaventura, M.V.; Gallelli, C.A.; Koczwara, J.B.; Smeets, D.; Giusepponi, M.E.; De Ceglia, M.; Friuli, M.; Micioni Di Bonaventura, E.; Scuderi, C.; et al. Oleoylethanolamide decreases frustration stress-induced binge-like eating in female rats: A novel potential treatment for binge eating disorder. Neuropsychopharmacol. Off. Publ. Am. College Neuropsychopharmacol. 2020. [CrossRef] [PubMed]

185. Filaferro, M.; Ruggieri, V.; Novi, C.; Calo, G.; Cifani, C.; Micioni Di Bonaventura, M.V.; Sandrini, M.; Vitale, G. Functional antagonism between nociceptin/orphanin FQ and corticotropin-releasing factor in rat anxiety-related behaviors: Involvement of the serotonergic system. Neuropeptides 2014, 48, 189-197. [CrossRef] [PubMed]

186. Bulik, C.M.; Kleiman, S.C.; Yilmaz, Z. Genetic epidemiology of eating disorders. Curr. Opin. Psychiatry 2016, 29, 383-388. [CrossRef]

187. Hubel, C.; Marzi, S.J.; Breen, G.; Bulik, C.M. Epigenetics in eating disorders: A systematic review. Mol. Psychiatry 2019, 24, 901-915. [CrossRef]

188. Mayhew, A.J.; Pigeyre, M.; Couturier, J.; Meyre, D. An Evolutionary Genetic Perspective of Eating Disorders. Neuroendocrinology 2018, 106, 292-306. [CrossRef]

189. Micioni Di Bonaventura, M.V.; Micioni Di Bonaventura, E.; Polidori, C.; Cifani, C. Preclinical Models of Stress and Environmental Influences on Binge Eating; Springer Nature Switzerland AG: Cham, Switzerland, 2020; pp. 85-101. [CrossRef]

190. Gervasini, G.; Gonzalez, L.M.; Gamero-Villarroel, C.; Mota-Zamorano, S.; Carrillo, J.A.; Flores, I.; Garcia-Herraiz, A. Effect of dopamine receptor D4 (DRD4) haplotypes on general psychopathology in patients with eating disorders. Gene 2018, 654, 43-48. [CrossRef]

191. American Psychiatric, A. Diagnostic and Statistical Manual of Mental Disorders: DSM-5; American Psychiatric Association: Arlington, VA, USA, 2013.

192. Bulik, C.M.; Sullivan, P.F.; Kendler, K.S. Medical and psychiatric morbidity in obese women with and without binge eating. Int. J. Eat. Disord. 2002, 32, 72-78. [CrossRef]

193. Volkow, N.D.; Wang, G.J.; Baler, R.D. Reward, dopamine and the control of food intake: Implications for obesity. Trends Cogn. Sci. 2011, 15, 37-46. [CrossRef]

194. Avena, N.M.; Rada, P.; Hoebel, B.G. Evidence for sugar addiction: Behavioral and neurochemical effects of intermittent, excessive sugar intake. Neurosci. Biobehav. Rev. 2008, 32, 20-39. [CrossRef] 
195. Dallman, M.F.; Pecoraro, N.; Akana, S.F.; La Fleur, S.E.; Gomez, F.; Houshyar, H.; Bell, M.E.; Bhatnagar, S.; Laugero, K.D.; Manalo, S. Chronic stress and obesity: A new view of "comfort food". Proc. Natl. Acad. Sci. USA 2003, 100, 11696-11701. [CrossRef] [PubMed]

196. Pecoraro, N.; Reyes, F.; Gomez, F.; Bhargava, A.; Dallman, M.F. Chronic stress promotes palatable feeding, which reduces signs of stress: Feedforward and feedback effects of chronic stress. Endocrinology 2004, 145, 3754-3762. [CrossRef] [PubMed]

197. Teegarden, S.L.; Bale, T.L. Effects of stress on dietary preference and intake are dependent on access and stress sensitivity. Physiol. Behav. 2008, 93, 713-723. [CrossRef]

198. Parylak, S.L.; Koob, G.F.; Zorrilla, E.P. The dark side of food addiction. Physiol. Behav. 2011, 104, $149-156$. [CrossRef] [PubMed]

199. Donofry, S.D.; Roecklein, K.A.; Rohan, K.J.; Wildes, J.E.; Kamarck, M.L. Prevalence and correlates of binge eating in seasonal affective disorder. Psychiatry Res. 2014, 217, 47-53. [CrossRef]

200. Kurlansik, S.L.; Ibay, A.D. Seasonal affective disorder. Am. Fam. Physician 2012, 86, 1037-1041.

201. Krauchi, K.; Reich, S.; Wirz-Justice, A. Eating style in seasonal affective disorder: Who will gain weight in winter? Compr. Psychiatry 1997, 38, 80-87. [CrossRef]

202. Rosenthal, N.E.; Genhart, M.; Jacobsen, F.M.; Skwerer, R.G.; Wehr, T.A. Disturbances of appetite and weight regulation in seasonal affective disorder. Ann. N. Y. Acad. Sci. 1987, 499, 216-230. [CrossRef]

203. Thaler, L.; Groleau, P.; Badawi, G.; Sycz, L.; Zeramdini, N.; Too, A.; Israel, M.; Joober, R.; Bruce, K.R.; Steiger, $\mathrm{H}$. Epistatic interactions implicating dopaminergic genes in bulimia nervosa (BN): Relationships to eating- and personality-related psychopathology. Prog. Neuro-Psychopharmacol. Biol. Psychiatry 2012, 39, 120-128. [CrossRef]

204. Hoek, H.W.; Van Hoeken, D. Review of the prevalence and incidence of eating disorders. Int. J. Eat. Disord. 2003, 34, 383-396. [CrossRef]

205. Keel, P.K.; Baxter, M.G.; Heatherton, T.F.; Joiner, T.E., Jr. A 20-year longitudinal study of body weight, dieting, and eating disorder symptoms. J. Abnorm. Psychol. 2007, 116, 422-432. [CrossRef] [PubMed]

206. Sikora, M.; Gese, A.; Czypicki, R.; Gasior, M.; Tretyn, A.; Chojnowski, J.; Bielinski, M.; Jaracz, M.; Kaminska, A.; Junik, R.; et al. Correlations between polymorphisms in genes coding elements of dopaminergic pathways and body mass index in overweight and obese women. Endokrynol. Pol. 2013, 64, 101-107. [PubMed]

207. Wang, G.J.; Volkow, N.D.; Fowler, J.S. The role of dopamine in motivation for food in humans: Implications for obesity. Expert Opin. Ther. Targets 2002, 6, 601-609. [CrossRef] [PubMed]

208. Levitan, R.D.; Masellis, M.; Lam, R.W.; Kaplan, A.S.; Davis, C.; Tharmalingam, S.; Mackenzie, B.; Basile, V.S.; Kennedy, J.L. A birth-season/DRD4 gene interaction predicts weight gain and obesity in women with seasonal affective disorder: A seasonal thrifty phenotype hypothesis. Neuropsychopharmacol. Off. Publ. Am. College Neuropsychopharmacol. 2006, 31, 2498-2503. [CrossRef] [PubMed]

209. Levitan, R.D.; Kaplan, A.S.; Davis, C.; Lam, R.W.; Kennedy, J.L. A season-of-birth/DRD4 interaction predicts maximal body mass index in women with bulimia nervosa. Neuropsychopharmacol. Off. Publ. Am. College Neuropsychopharmacol. 2010, 35, 1729-1733. [CrossRef]

210. Van Strien, T.; Levitan, R.D.; Engels, R.C.; Homberg, J.R. Season of birth, the dopamine D4 receptor gene and emotional eating in males and females. Evidence of a genetic plasticity factor? Appetite 2015, 90, 51-57. [CrossRef]

211. Van Strien, T.; Cebolla, A.; Etchemendy, E.; Gutierrez-Maldonado, J.; Ferrer-Garcia, M.; Botella, C.; Banos, R. Emotional eating and food intake after sadness and joy. Appetite 2013, 66, 20-25. [CrossRef]

212. Micioni Di Bonaventura, M.V.; Lutz, T.A.; Romano, A.; Pucci, M.; Geary, N.; Asarian, L.; Cifani, C. Estrogenic suppression of binge-like eating elicited by cyclic food restriction and frustrative-nonreward stress in female rats. Int. J. Eat. Disord. 2017, 50, 624-635. [CrossRef]

213. Turton, R.; Chami, R.; Treasure, J. Emotional Eating, Binge Eating and Animal Models of Binge-Type Eating Disorders. Curr. Obes. Rep. 2017, 6, 217-228. [CrossRef]

214. Van Strien, T. Causes of Emotional Eating and Matched Treatment of Obesity. Curr. Diabetes Rep. 2018, 18, 35. [CrossRef]

215. Silveira, P.P.; Portella, A.K.; Kennedy, J.L.; Gaudreau, H.; Davis, C.; Steiner, M.; Soares, C.N.; Matthews, S.G.; Sokolowski, M.B.; Dube, L.; et al. Association between the seven-repeat allele of the dopamine-4 receptor gene (DRD4) and spontaneous food intake in pre-school children. Appetite 2014, 73, 15-22. [CrossRef] [PubMed] 
216. Silveira, P.P.; Gaudreau, H.; Atkinson, L.; Fleming, A.S.; Sokolowski, M.B.; Steiner, M.; Kennedy, J.L.; Meaney, M.J.; Levitan, R.D.; Dube, L. Genetic Differential Susceptibility to Socioeconomic Status and Childhood Obesogenic Behavior: Why Targeted Prevention May Be the Best Societal Investment. JAMA Pediatrics 2016, 170, 359-364. [CrossRef] [PubMed]

217. Barth, B.; Bizarro, L.; Miguel, P.M.; Dube, L.; Levitan, R.; O’Donnell, K.; Meaney, M.J.; Silveira, P.P. Genetically predicted gene expression of prefrontal DRD4 gene and the differential susceptibility to childhood emotional eating in response to positive environment. Appetite 2020, 148, 104594. [CrossRef] [PubMed]

218. Levitan, R.D.; Jansen, P.; Wendland, B.; Tiemeier, H.; Jaddoe, V.W.; Silveira, P.P.; Kennedy, J.L.; Atkinson, L.; Fleming, A.; Sokolowski, M.; et al. A DRD4 gene by maternal sensitivity interaction predicts risk for overweight or obesity in two independent cohorts of preschool children. J. Child Psychol. Psychiatry Allied Discip. 2017, 58, 180-188. [CrossRef]

219. Stice, E.; Yokum, S.; Bohon, C.; Marti, N.; Smolen, A. Reward circuitry responsivity to food predicts future increases in body mass: Moderating effects of DRD2 and DRD4. NeuroImage 2010, 50, 1618-1625. [CrossRef]

220. Stice, E.; Spoor, S.; Bohon, C.; Veldhuizen, M.G.; Small, D.M. Relation of reward from food intake and anticipated food intake to obesity: A functional magnetic resonance imaging study. J. Abnorm. Psychol. 2008, 117, 924-935. [CrossRef]

221. Stice, E.; Yokum, S.; Burger, K.; Epstein, L.; Smolen, A. Multilocus genetic composite reflecting dopamine signaling capacity predicts reward circuitry responsivity. J. Neurosci. Off. J. Soc. Neurosci. 2012, 32, 10093-10100. [CrossRef]

222. Gervasini, G.; Gordillo, I.; Garcia-Herraiz, A.; Flores, I.; Jimenez, M.; Monge, M.; Carrillo, J.A. Influence of dopamine polymorphisms on the risk for anorexia nervosa and associated psychopathological features. J. Clin. Psychopharmacol. 2013, 33, 551-555. [CrossRef]

223. Rask-Andersen, M.; Olszewski, P.K.; Levine, A.S.; Schioth, H.B. Molecular mechanisms underlying anorexia nervosa: Focus on human gene association studies and systems controlling food intake. Brain Res. Rev. 2010, 62, 147-164. [CrossRef]

224. Hinney, A.; Schneider, J.; Ziegler, A.; Lehmkuhl, G.; Poustka, F.; Schmidt, M.H.; Mayer, H.; Siegfried, W.; Remschmidt, H.; Hebebrand, J. No evidence for involvement of polymorphisms of the dopamine D4 receptor gene in anorexia nervosa, underweight, and obesity. Am. J. Med. Genet. 1999, 88, 594-597. [CrossRef]

225. Guo, G.; North, K.; Choi, S. DRD4 gene variant associated with body mass: The National Longitudinal Study of Adolescent Health. Hum. Mutat. 2006, 27, 236-241. [CrossRef] [PubMed]

226. Guo, G.; North, K.E.; Gorden-Larsen, P.; Bulik, C.M.; Choi, S. Body mass, DRD4, physical activity, sedentary behavior, and family socioeconomic status: The add health study. Obesity 2007, 15, 1199-1206. [CrossRef] [PubMed]

227. Fontana, C.; Vitolo, M.R.; Campagnolo, P.D.; Mattevi, V.S.; Genro, J.P.; Almeida, S. DRD4 and SLC6A3 gene polymorphisms are associated with food intake and nutritional status in children in early stages of development. J. Nutr. Biochem. 2015, 26, 1607-1612. [CrossRef] [PubMed]

228. Fuemmeler, B.F.; Agurs-Collins, T.D.; McClernon, F.J.; Kollins, S.H.; Kail, M.E.; Bergen, A.W.; Ashley-Koch, A.E. Genes implicated in serotonergic and dopaminergic functioning predict BMI categories. Obesity 2008, 16, 348-355. [CrossRef]

229. Yokum, S.; Marti, C.N.; Smolen, A.; Stice, E. Relation of the multilocus genetic composite reflecting high dopamine signaling capacity to future increases in BMI. Appetite 2015, 87, 38-45. [CrossRef]

230. Karwautz, A.; Rabe-Hesketh, S.; Hu, X.; Zhao, J.; Sham, P.; Collier, D.A.; Treasure, J.L. Individual-specific risk factors for anorexia nervosa: A pilot study using a discordant sister-pair design. Psychol. Med. 2001, 31, 317-329. [CrossRef]

231. Yilmaz, Z.; Kaplan, A.S.; Levitan, R.D.; Zai, C.C.; Kennedy, J.L. Possible association of the DRD4 gene with a history of attention-deficit/hyperactivity disorder in women with bulimia nervosa. Int. J. Eat. Disord. 2012, 45, 622-625. [CrossRef]

232. Frieling, H.; Romer, K.D.; Scholz, S.; Mittelbach, F.; Wilhelm, J.; De Zwaan, M.; Jacoby, G.E.; Kornhuber, J.; Hillemacher, T.; Bleich, S. Epigenetic dysregulation of dopaminergic genes in eating disorders. Int. J. Eat. Disord. 2010, 43, 577-583. [CrossRef]

233. Thanos, P.K.; Habibi, R.; Michaelides, M.; Patel, U.B.; Suchland, K.; Anderson, B.J.; Robinson, J.K.; Wang, G.J.; Grandy, D.K.; Volkow, N.D. Dopamine D4 receptor (D4R) deletion in mice does not affect operant responding for food or cocaine. Behav. Brain Res. 2010, 207, 508-511. [CrossRef] 
234. Soto, P.L.; Hiranita, T.; Xu, M.; Hursh, S.R.; Grandy, D.K.; Katz, J.L. Dopamine D(2)-Like Receptors and Behavioral Economics of Food Reinforcement. Neuropsychopharmacol. Off. Publ. Am. College Neuropsychopharmacol. 2016, 41, 971-978. [CrossRef]

235. Lee, M.D.; Clifton, P.G. Meal patterns of free feeding rats treated with clozapine, olanzapine, or haloperidol. Pharmacol. Biochem. Behav. 2002, 71, 147-154. [CrossRef]

236. Kaur, G.; Kulkarni, S.K. Studies on modulation of feeding behavior by atypical antipsychotics in female mice. Prog. Neuro-Psychopharmacol. Biol. Psychiatry 2002, 26, 277-285. [CrossRef]

237. Bromel, T.; Blum, W.F.; Ziegler, A.; Schulz, E.; Bender, M.; Fleischhaker, C.; Remschmidt, H.; Krieg, J.C.; Hebebrand, J. Serum leptin levels increase rapidly after initiation of clozapine therapy. Mol. Psychiatry 1998, 3, 76-80. [CrossRef] [PubMed]

238. Theisen, F.M.; Linden, A.; Konig, I.R.; Martin, M.; Remschmidt, H.; Hebebrand, J. Spectrum of binge eating symptomatology in patients treated with clozapine and olanzapine. J. Neural Transm. 2003, 110, 111-121. [CrossRef] [PubMed]

239. Leadbetter, R.; Shutty, M.; Pavalonis, D.; Vieweg, V.; Higgins, P.; Downs, M. Clozapine-induced weight gain: Prevalence and clinical relevance. Am. J. Psychiatry 1992, 149, 68-72. [CrossRef]

240. Moore, N.A. Behavioural pharmacology of the new generation of antipsychotic agents. Br. J. Psychiatry Suppl. 1999, 5-11. [CrossRef]

241. Baptista, T. Body weight gain induced by antipsychotic drugs: Mechanisms and management. Acta Psychiatr. Scand. 1999, 100, 3-16. [CrossRef]

242. Huang, X.F.; Yu, Y.; Zavitsanou, K.; Han, M.; Storlien, L. Differential expression of dopamine D2 and D4 receptor and tyrosine hydroxylase mRNA in mice prone, or resistant, to chronic high-fat diet-induced obesity. Brain Res. Mol. Brain Res. 2005, 135, 150-161. [CrossRef]

243. Cifani, C.; Micioni Di Bonaventura, M.V.; Pucci, M.; Giusepponi, M.E.; Romano, A.; Di Francesco, A.; Maccarrone, M.; D'Addario, C. Regulation of hypothalamic neuropeptides gene expression in diet induced obesity resistant rats: Possible targets for obesity prediction? Front. Neurosci. 2015, 9, 187. [CrossRef]

244. Hochberg, I.; Hochberg, Z. Expanding the definition of hypothalamic obesity. Obes. Rev. Off. J. Int. Assoc. Study Obes. 2010, 11, 709-721. [CrossRef]

245. Morton, G.J.; Cummings, D.E.; Baskin, D.G.; Barsh, G.S.; Schwartz, M.W. Central nervous system control of food intake and body weight. Nature 2006, 443, 289-295. [CrossRef] [PubMed]

246. Micioni Di Bonaventura, M.V.; Micioni Di Bonaventura, E.; Cifani, C.; Polidori, C. N/OFQ-NOP System in Food Intake. Handb. Exp. Pharmacol. 2019, 254, 279-295. [CrossRef] [PubMed]

247. Micioni Di Bonaventura, M.V.; Ubaldi, M.; Liberati, S.; Ciccocioppo, R.; Massi, M.; Cifani, C. Caloric restriction increases the sensitivity to the hyperphagic effect of nociceptin/orphanin FQ limiting its ability to reduce binge eating in female rats. Psychopharmacology 2013, 228, 53-63. [CrossRef] [PubMed]

248. Alboni, S.; Micioni Di Bonaventura, M.V.; Benatti, C.; Giusepponi, M.E.; Brunello, N.; Cifani, C. Hypothalamic expression of inflammatory mediators in an animal model of binge eating. Behav. Brain Res. 2017, 320, 420-430. [CrossRef]

249. Cifani, C.; Micioni Di Bonaventura, M.V.; Cannella, N.; Fedeli, A.; Guerrini, R.; Calo, G.; Ciccocioppo, R.; Ubaldi, M. Effect of neuropeptide $\mathrm{S}$ receptor antagonists and partial agonists on palatable food consumption in the rat. Peptides 2011, 32, 44-50. [CrossRef]

250. Kania, A.; Szlaga, A.; Sambak, P.; Gugula, A.; Blasiak, E.; Micioni Di Bonaventura, M.V.; Hossain, M.A.; Cifani, C.; Hess, G.; Gundlach, A.L.; et al. RLN3/RXFP3 Signaling in the PVN Inhibits Magnocellular Neurons via M-like Current Activation and Contributes to Binge Eating Behavior. J. Neurosci. Off. J. Soc. Neurosci. 2020, 40, 5362-5375. [CrossRef]

251. Piccoli, L.; Micioni Di Bonaventura, M.V.; Cifani, C.; Costantini, V.J.; Massagrande, M.; Montanari, D.; Martinelli, P.; Antolini, M.; Ciccocioppo, R.; Massi, M.; et al. Role of orexin-1 receptor mechanisms on compulsive food consumption in a model of binge eating in female rats. Neuropsychopharmacol. Off. Publ. Am. College Neuropsychopharmacol. 2012, 37, 1999-2011. [CrossRef]

252. Pucci, M.; Micioni Di Bonaventura, M.V.; Vezzoli, V.; Zaplatic, E.; Massimini, M.; Mai, S.; Sartorio, A.; Scacchi, M.; Persani, L.; Maccarrone, M.; et al. Preclinical and Clinical Evidence for a Distinct Regulation of Mu Opioid and Type 1 Cannabinoid Receptor Genes Expression in Obesity. Front. Genet. 2019, 10, 523. [CrossRef] 
253. Pucci, M.; Micioni Di Bonaventura, M.V.; Zaplatic, E.; Bellia, F.; Maccarrone, M.; Cifani, C.; D’Addario, C. Transcriptional regulation of the endocannabinoid system in a rat model of binge-eating behavior reveals a selective modulation of the hypothalamic fatty acid amide hydrolase gene. Int. J. Eat. Disord. 2019. [CrossRef]

254. Romano, A.; Karimian Azari, E.; Tempesta, B.; Mansouri, A.; Micioni Di Bonaventura, M.V.; Ramachandran, D.; Lutz, T.A.; Bedse, G.; Langhans, W.; Gaetani, S. High dietary fat intake influences the activation of specific hindbrain and hypothalamic nuclei by the satiety factor oleoylethanolamide. Physiol. Behav. 2014, 136, 55-62. [CrossRef]

255. Saper, C.B.; Lowell, B.B. The hypothalamus. Curr. Biol. CB 2014, 24, R1111-R1116. [CrossRef] [PubMed]

256. Bazhan, N.; Zelena, D. Food-intake regulation during stress by the hypothalamo-pituitary-adrenal axis. Brain Res. Bull. 2013, 95, 46-53. [CrossRef] [PubMed]

257. Spencer, S.J. Perinatal programming of neuroendocrine mechanisms connecting feeding behavior and stress. Front. Neurosci. 2013, 7, 109. [CrossRef] [PubMed]

258. Calo, G.; Rizzi, A.; Cifani, C.; Micioni Di Bonaventura, M.V.; Regoli, D.; Massi, M.; Salvadori, S.; Lambert, D.G.; Guerrini, R. UFP-112 a potent and long-lasting agonist selective for the Nociceptin/Orphanin FQ receptor. CNS Neurosci. Ther. 2011, 17, 178-198. [CrossRef] [PubMed]

259. Tejas-Juarez, J.G.; Cruz-Martinez, A.M.; Lopez-Alonso, V.E.; Garcia-Iglesias, B.; Mancilla-Diaz, J.M.; Floran-Garduno, B.; Escartin-Perez, R.E. Stimulation of dopamine D4 receptors in the paraventricular nucleus of the hypothalamus of male rats induces hyperphagia: Involvement of glutamate. Physiol. Behav. 2014, 133, 272-281. [CrossRef] [PubMed]

260. Aubry, J.M.; Bartanusz, V.; Pagliusi, S.; Schulz, P.; Kiss, J.Z. Expression of ionotropic glutamate receptor subunit mRNAs by paraventricular corticotropin-releasing factor (CRF) neurons. Neurosci. Lett. 1996, 205, 95-98. [CrossRef]

261. Borroto-Escuela, D.O.; Ferraro, L.; Narvaez, M.; Tanganelli, S.; Beggiato, S.; Liu, F.; Rivera, A.; Fuxe, K. Multiple Adenosine-Dopamine (A2A-D2 Like) Heteroreceptor complexes in the brain and their role in schizophrenia. Cells 2020, 9, 1077. [CrossRef]

262. Fuxe, K.; Marcellino, D.; Borroto-Escuela, D.O.; Guescini, M.; Fernandez-Duenas, V.; Tanganelli, S.; Rivera, A.; Ciruela, F.; Agnati, L.F. Adenosine-dopamine interactions in the pathophysiology and treatment of CNS disorders. CNS Neurosci. Ther. 2010, 16, e18-e42. [CrossRef]

263. Woods, A.S. The dopamine $\mathrm{D}(4)$ receptor, the ultimate disordered protein. J. Recept. Signal Transduct. Res. 2010, 30, 331-336. [CrossRef]

264. Filip, M.; Zaniewska, M.; Frankowska, M.; Wydra, K.; Fuxe, K. The importance of the adenosine A(2A) receptor-dopamine $\mathrm{D}(2)$ receptor interaction in drug addiction. Curr. Med. Chem. 2012, 19, 317-355. [CrossRef]

265. Micioni Di Bonaventura, M.V.; Cifani, C.; Lambertucci, C.; Volpini, R.; Cristalli, G.; Froldi, R.; Massi, M. Effects of $\mathrm{A}(2) \mathrm{A}$ adenosine receptor blockade or stimulation on alcohol intake in alcohol-preferring rats. Psychopharmacology 2012, 219, 945-957. [CrossRef] [PubMed]

266. Micioni Di Bonaventura, M.V.; Cifani, C.; Lambertucci, C.; Volpini, R.; Cristalli, G.; Massi, M. A2A adenosine receptor agonists reduce both high-palatability and low-palatability food intake in female rats. Behav. Pharmacol. 2012, 23, 567-574. [CrossRef] [PubMed]

267. Micioni Di Bonaventura, M.V.; Pucci, M.; Giusepponi, M.E.; Romano, A.; Lambertucci, C.; Volpini, R.; Micioni Di Bonaventura, E.; Gaetani, S.; Maccarrone, M.; D’Addario, C.; et al. Regulation of adenosine A2A receptor gene expression in a model of binge eating in the amygdaloid complex of female rats. J. Psychopharmacol. 2019. [CrossRef] [PubMed]

268. Wydra, K.; Gawlinski, D.; Gawlinska, K.; Frankowska, M.; Borroto-Escuela, D.O.; Fuxe, K.; Filip, M. Adenosine A2AReceptors in substance use disorders: A focus on cocaine. Cells 2020, 9, 1372. [CrossRef] [PubMed]

269. Lee, I.T.; Chen, S.; Schetz, J.A. An unambiguous assay for the cloned human sigma1 receptor reveals high affinity interactions with dopamine D4 receptor selective compounds and a distinct structure-affinity relationship for butyrophenones. Eur. J. Pharmacol. 2008, 578, 123-136. [CrossRef]

270. Del Bello, F.; Bonifazi, A.; Giorgioni, G.; Cifani, C.; Micioni Di Bonaventura, M.V.; Petrelli, R.; Piergentili, A.; Fontana, S.; Mammoli, V.; Yano, H.; et al. 1-[3-(4-Butylpiperidin-1-yl)propyl]-1,2,3,4-tetrahydroquinolin-2-one (77-LH-28-1) as a model for the rational design of a novel class of brain penetrant ligands with high affinity and selectivity for dopamine $\mathrm{d} 4$ receptor. J. Med. Chem. 2018, 61, 3712-3725. [CrossRef] 
271. Cottone, P.; Wang, X.; Park, J.W.; Valenza, M.; Blasio, A.; Kwak, J.; Iyer, M.R.; Steardo, L.; Rice, K.C.; Hayashi, T.; et al. Antagonism of sigma-1 receptors blocks compulsive-like eating. Neuropsychopharmacol. Off. Publ. Am. College Neuropsychopharmacol. 2012, 37, 2593-2604. [CrossRef]

272. Del Bello, F.; Micioni Di Bonaventura, M.V.; Bonifazi, A.; Wunsch, B.; Schepmann, D.; Giancola, J.B.; Di Bonaventura, E.M.; Vistoli, G.; Giorgioni, G.; Quaglia, W.; et al. Investigation of the role of chirality in the interaction with sigma receptors and effect on binge eating episode of a potent sigma1 antagonist analogue of spipethiane. ACS Chem. Neurosci. 2019. [CrossRef]

273. Quadir, S.G.; Cottone, P.; Sabino, V. Role of sigma receptors in alcohol addiction. Front. Pharmacol. 2019, $10,687$. [CrossRef]

274. Sabino, V.; Hicks, C.; Cottone, P. Sigma receptors and substance use disorders. Adv. Exp. Med. Biol. 2017, 964, 177-199. [CrossRef]

(C) 2020 by the authors. Licensee MDPI, Basel, Switzerland. This article is an open access article distributed under the terms and conditions of the Creative Commons Attribution (CC BY) license (http://creativecommons.org/licenses/by/4.0/). 